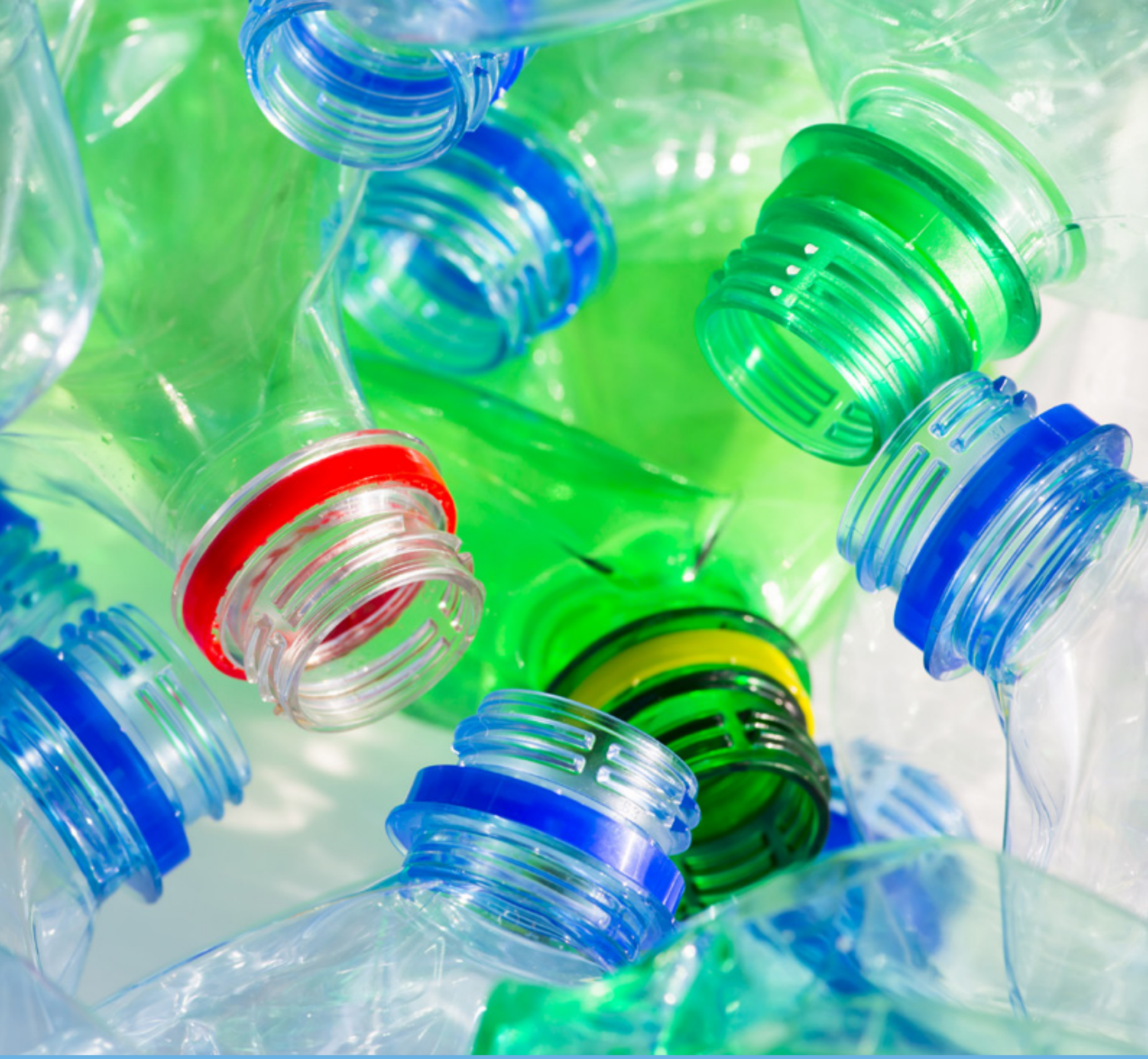

Biobased materialen, circulaire economie en natuurlijk kapitaal 

Biobased materialen, circulaire economie en natuurlijk kapitaal 
Dit Technical report is gemaakt conform het Kwaliteitsmanagementsysteem (KMS) van de unit Wettelijke Onderzoekstaken Natuur \& Milieu, onderdeel van Wageningen University \& Research.

De WOT Natuur \& Milieu voert wettelijke onderzoekstaken uit op het beleidsterrein natuur en milieu. Deze taken worden uitgevoerd om een wettelijke verantwoordelijkheid van de minister van Economische Zaken te ondersteunen. De WOT Natuur \& Milieu werkt aan producten van het Planbureau voor de Leefomgeving, zoals de Balans van de Leefomgeving en de Natuurverkenning. Verder brengen we voor het ministerie van Economische Zaken adviezen uit over (toelating van) meststoffen en bestrijdingsmiddelen, en zorgen we voor informatie voor Europese rapportageverplichtingen over biodiversiteit.

De reeks 'WOt-technical reports' bevat onderzoeksresultaten van projecten die kennisorganisaties voor de unit Wettelijke Onderzoekstaken Natuur \& Milieu hebben uitgevoerd.

Dit onderzoek is uitgevoerd in opdracht van het Planbureau voor de Leefomgeving (PBL). Het PBL is een inhoudelijk onafhankelijk onderzoeksinstituut op het gebied van milieu, natuur en ruimte, zoals gewaarborgd in de Aanwijzingen voor de Planbureaus, Staatscourant 3200, 21 februari 2012.

Het onderzoek is gefinancierd door het Ministerie van Landbouw, Natuur en Voedselkwaliteit (LNV). 


\section{Biobased materialen, circulaire economie en natuurlijk kapitaal}

M.M.M. Overbeek, E.M.W. Smeets \& A.D. Verhoog 


\section{Referaat}

Overbeek, M.M.M., E.M.W. Smeets \& A.D. Verhoog (2017). Biobased materialen, circulaire economie en natuurlijk kapitaal. Wageningen, Wettelijke Onderzoekstaken Natuur \& Milieu, WUR. WOt-technical report 109. 38 blz.; 6 fig.; 1 tab.; 33 ref.

Deze voorstudie gaat in op hoeveel biomassa in Nederland nodig is om de fossiele grondstoffen in plastic te vervangen en hoe de hierbij gevraagde transitie naar biobased plastics kan worden gerealiseerd. Hiervoor is gebruik gemaakt van deskresearch, en is berekend hoeveel landbouwgrond nodig zou zijn om voldoende biobased materiaal te produceren voor de Nederlandse behoefte aan biobased plastics. Verder zijn interviews met deskundigen gehouden over de institutionele belemmeringen die een transitie in de weg staan. In Nederland is veel te weinig cultuurgrond beschikbaar om de benodigde biomassa te produceren om fossiele plastics te kunnen vervangen. Onderzoek dat de bijdrage van biobased materialen aan de circulaire economie wil versterken, moet zich richten op de beoordeling van de opties om duurzame grondstoffen te realiseren en het integraal afwegen van duurzaam gebruik van biomassa in diverse toepassingen.

Trefwoorden: biobased, biomassa, plastics, landgebruik, circulair.

\section{Abstract}

Overbeek, M.M.M., E.M.W. Smeets \& A.D. Verhoog (2017). Biobased materials, the circular economy and natural capital. Wageningen, Statutory Research Tasks Unit for Nature \& the Environment, WUR. WOttechnical report 109. 38 p.; 6 Figs; 1 Tab.; 33 Refs.

This preliminary study investigates the amount of biomass that would be needed in the Netherlands to replace the fossil raw materials used in the manufacture of plastics and how this transition to biobased plastics can be achieved. It is based on desk research and calculations of the area of agricultural land that would be needed to produce sufficient biobased material to meet Dutch demand for biobased plastics. In addition, interviews were held with experts on the institutional obstacles to such a transition. Far too little agricultural land is available in the Netherlands to produce the required amount of biomass needed to replace fossil plastics. Research with the aim of increasing the contribution made by biobased materials to the circular economy should focus on assessing the options for producing sustainable raw materials and on a comprehensive assessment of the sustainable use of biomass in various applications.

Keywords: biobased, biomass, plastics, land use, circular

\section{(C) 2017 Wageningen Economic Research}

Postbus 29703, 2502 LS Den Haag

Tel: (070) 33583 30; e-mail: informatie.lei@wur.nl

De reeks WOt-technical reports is een uitgave van de unit Wettelijke Onderzoekstaken Natuur \& Milieu, onderdeel van Wageningen University \& Research. Dit technical report is verkrijgbaar bij het secretariaat. De publicatie is ook te downloaden via www.wur.nl/wotnatuurenmilieu.

Wettelijke Onderzoekstaken Natuur \& Milieu, Postbus 47, 6700 AA Wageningen

Tel: (0317) 4854 71; e-mail: info.wnm@wur.nl; Internet: www.wur.nl/wotnatuurenmilieu.

Alle rechten voorbehouden. Niets uit deze uitgave mag worden verveelvoudigd en/of openbaar gemaakt door middel van druk, fotokopie, microfilm of op welke andere wijze ook zonder voorafgaande schriftelijke toestemming van de uitgever. De uitgever aanvaardt geen aansprakelijkheid voor eventuele schade voortvloeiend uit het gebruik van de resultaten van dit onderzoek of de toepassing van de adviezen. 


\section{Woord vooraf}

Nederland gebruikt veel fossiele grondstoffen die volgens de rijksoverheid vaker dienen te worden hergebruikt of te worden vervangen door plantaardige grondstoffen. Plantaardige grondstoffen kunnen niet alleen efficiënter dan nu worden ingezet in foodtoepassingen, zoals in de eiwittransitie, maar kunnen ook voor non-foodtoepassingen worden gebruikt, zoals in de biobased economie. Biobased producten kunnen een belangrijke bijdrage leveren aan de transitie van een lineaire naar een circulaire economie, maar dat is niet vanzelfsprekend. In dit project verkennen we de relatie tussen biobased plastics, circulaire economie en landgebruik (als indicator voor natuurlijk kapitaal). De vraag is in hoeverre er in Nederland voldoende cultuurgrond beschikbaar is om de benodigde plantaardige grondstoffen te telen en hoe het gebruik van bioplastics kan worden gestimuleerd.

Om deze vragen van een antwoord te voorzien, is een desk studie uitgevoerd naar biobased plastics en is de orde van grootte berekend van de benodigde hoeveelheid hectares cultuurgrond om de benodigde plantaardige grondstoffen te telen. Verder zijn er deskundigen geïnterviewd die op verschillende manieren bij de transitie naar een biobased economie zijn betrokken, namelijk Christiaan Bolck (Wageningen Food en Biobased Research), Harmen Willemse (NEN), Jelmer Vierstra (Stichting Natuur \& Milieu) en Rop Zoetemeyer (Stichting Biobased Delta).

Deze voorstudie toont het zoekproces vanuit een maatschappelijk perspectief bij stakeholders en onderzoekers in de wereld van chemie en natuur. Wij zijn daarbij ondersteund door een meedenkende opdrachtgever van het Planbureau voor de Leefomgeving (PBL), Arjan Ruijs, en de WOT-themacoördinator, Martijn van der Heide.

Wij danken de geïnterviewden voor de gesprekken en hun reviews van het rapport en de opdrachtgevers voor hun bijdrage aan de realisatie ervan. 



\section{Inhoud}

Woord vooraf

Summary

$1 \quad$ Inleiding

$\begin{array}{lll}1.1 & \text { Aanleiding } & 13\end{array}$

1.2 Doelstelling, onderzoeksvragen en methode $\quad 14$

$\begin{array}{lll}1.3 & \text { Inhoud van dit rapport } & 15\end{array}$

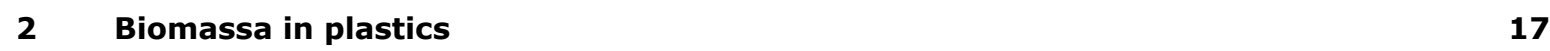

$\begin{array}{lll}2.1 & \text { Inleiding } & 17\end{array}$

2.2 Toepassingen van biobased plastics in een circulaire economie 17

$\begin{array}{ll}2.3 & \text { Landbouwgrond in Nederland om biomassa te telen } \\ 2.4\end{array}$

$\begin{array}{lll}2.4 & \text { Externe impacts van biomassa op natuur en milieu } & 23\end{array}$

$3 \quad$ Naar duurzame biobased plastics $\quad 25$

$\begin{array}{lll}3.1 & \text { Introductie } & 25\end{array}$

$\begin{array}{lll}3.2 & \text { Toegevoegde waarde van biomassa } & 25\end{array}$

$\begin{array}{lll}3.3 & \text { Ontwikkeling biobased plastics } & 26\end{array}$

$\begin{array}{lll}3.4 & \text { Standardisatie en certificering duurzaamheidscriteria } & 27\end{array}$

$\begin{array}{ll}3.5 & \text { Vraag vanuit de markt }\end{array}$

4 Slotbeschouwing $\quad 31$

$\begin{array}{lll}4.1 & \text { Conclusies } & 31\end{array}$

$\begin{array}{ll}4.2 & \text { Aandachtspunten voor verder onderzoek } \\ \end{array}$

$\begin{array}{ll}\text { Literatuur } & 33\end{array}$

$\begin{array}{ll}\text { Verantwoording } & 35\end{array}$ 



\title{
Samenvatting
}

\begin{abstract}
Doel en methode
Een duurzame bijdrage van de biobased economie aan de circulaire economie vraagt meer inzicht in de relatie tussen biobased materialen, grondstoffen en landgebruik. Het doel van dit onderzoek is om meer inzicht te krijgen in hoeverre fossiele grondstoffen in plastics door plantaardige biomassa kunnen worden vervangen en of de bijbehorende transitie naar duurzame biobased plastics in gang kan worden gezet. Hiervoor is een literatuuronderzoek verricht, zijn interviews met deskundigen gehouden en is als gedachte-experiment een berekening gemaakt hoeveel hectares cultuurgrond in Nederland nodig zouden zijn om fossiel- door bio-based plastics te kunnen vervangen.
\end{abstract}

\section{Resultaten}

\section{Relatie tussen het gebruik van biomassa in plastics, circulaire economie en landgebruik} Biobased materialen zijn (deels) gemaakt van plantaardige grondstoffen. Belangrijke toepassingen zijn verpakkingen. De bijdrage van biobased plastics aan de circulaire economie is nog beperkt. Belangrijke voorbeelden zijn bio-petflessen en bio-PE-draagtassen en -flacons. Slechts een klein deel van de biobased plastics is biologisch afbreekbaar zoals PLA (polyactide) dat wordt gebruikt in voedselverpakkingen zoals plastic bakjes, folies en foam. Wereldwijd is het gebruik van land voor biomassa voor plastics nog klein. In Nederland zijn echter veel te weinig hectares cultuurgrond beschikbaar voor het telen van biomassa om de hier gebruikte fossiele plastics te kunnen vervangen door biobased plastics, tenzij in Nederland nog alleen maar suikerbieten zouden worden geteeld. Bovendien verwacht de chemische industrie technisch gezien maar een klein deel van de benodigde biobased plastics te kunnen maken.

\section{Uitdagingen voor een transitie naar duurzame biobased plastics}

Gegeven de grote, bijna onrealistische, hoeveelheid cultuurgrond die nodig is om biomassa voor plastics (eerste generatie) te telen, kan meer gebruik van reststromen (tweede generatie) uitkomst bieden. Dit gebeurt nu nog niet. Daarnaast is ook in de voorlopende regio's in Europa, zoals in Zuidwest-Nederland en Vlaanderen, nog nauwelijks een waardeketen ontwikkeld dat alle actoren van boer tot consument verbindt en tot een maatschappelijke vraag naar biobased plastics leidt. Wettelijke duurzaamheidseisen van biomassa voor biobased producten zijn nu nog niet geharmoniseerd in Europa. Het beleid voor biobrandstoffen kan aanknopingspunten bieden voor duurzame biobased materialen, maar houdt weinig rekening met (in)directe veranderingen in landgebruik, voedselzekerheid en ontbossing. Om vrijwillige afspraken over meer duurzaamheid te realiseren zijn certificeringsschema's voor duurzame biobrandstoffen aangepast voor biobased materialen (Better Biomass, RSB en ISCC-PLUS). Een belangrijke behoefte voor wetgeving en certificering is dat de duurzaamheidsclaims wetenschappelijk beter worden onderbouwd.

Biobased plastics bieden nog weinig voordelen qua functie en prijs ten opzichte van fossiele plastics. Biobased innovaties zouden zich meer op de eigenschappen van de gebruikte biomassa moeten richten (minder gewicht, betere afbreekbaarheid, langere houdbaarheid). Ook begrijpen potentiële kopers de betekenis van het begrip biobased niet. $\mathrm{Er}$ is in Nederland geen wetgeving dat het gebruik van biobased (indirect) stimuleert. Op Europees niveau wordt hiervoor wetgeving voorbereid. $\mathrm{Er}$ ontbreekt een tool waarmee op basis van people, planet en profit een afweging kan worden gemaakt waarvoor biomassa de meest zinvolle toepassing is (brandstof, producten, voedsel of cosmetica).

\section{Aanbevelingen}

Onderzoek dat de maatschappelijke bijdrage van biobased materialen aan de circulaire economie wil versterken, moet zich meer richten op:

- Beoordelen van de opties om duurzame grondstoffen te realiseren (meer reststromen, intensiever landgebruik en meer hergebruik van fossiele plastics).

- Integraal afwegen van duurzaam gebruik van biomassa bij de keuze tussen toepassingen. 


\title{
Summary
}

\begin{abstract}
Aim and method
For the biobased economy to make a sustainable contribution to the circular economy, more needs to be known about the relation between biobased materials, raw materials and land use. The aim of this research is to learn more about how much of the fossil raw materials used in the manufacture of plastics can be replaced by plant-based biomass and whether such as transition to sustainable biobased plastics. A literature study was carried out, interviews were held with experts and, as a thought experiment, calculations were made of the area of agricultural land in the Netherlands that would be needed to be able to replace fossil plastics with biobased plastics.
\end{abstract}

\section{Results}

\section{Relation between the use of biomass in plastics, the circular economy and land use} Biobased materials are made (partly) from plant-based raw materials. The main applications are in packaging materials. At the moment, biobased plastics only make a limited contribution to the circular economy, the main examples being bio-PET bottles and bio-PE carrier bags and bottles. Only a small fraction of biobased plastics are biodegradable; this includes PLA (polylactide), which is used in food packaging materials such as plastic trays, foils and foam. The area of land used for cultivating biomass worldwide is still small. In the Netherlands, though, there is too little agricultural land available to cultivate enough biomass to be able to replace fossil plastics with biobased plastics, unless sugar beet were the only crop to be cultivated throughout the whole country. Moreover, the chemical industry expects for technical reasons that it will only be able to manufacture a small fraction of the required bioplastics.

\section{Challenges in making the transition to sustainable biobased plastics}

Given the large and unrealistic amount of agricultural land that would be needed to cultivate the biomass required to make these plastics (first generation), making greater use of waste-derived feedstocks (second generation) could be a solution. This is not being done yet. In addition, even in the frontrunner regions in Europe, such as south-west Netherlands and Flanders, there is as yet little sign of an established value chain from farmers to consumers and an accompanying consumer demand for biobased plastics. Statutory sustainability requirements for biobased products have not yet been harmonised across Europe. The policy for biofuels could provide a starting point, but this takes little account of direct or indirect changes in land use, food security and deforestation. Certification schemes for sustainable biofuels have been adapted for use in voluntary agreements on more sustainable production of biobased materials (Better Biomass, RSB and ISCC-PLUS), but legislation and certification will depend crucially on sustainability claims being more rigorously substantiated with empirical data.

Biobased plastics still present too few functionality and price advantages over fossil plastics. Biobased innovations should focus more on exploiting the properties of the biomass used (e.g. lighter, more biodegradable, longer shelf life). Even so, potential customers do not fully understand what 'biobased' means. In the Netherlands there is no legislation that encourages (indirectly) the use of biobased materials, but European legislation with this aim is currently under preparation. However, there is no tool that can be used to make a 'people, planet, profit' assessment of where biomass can most usefully be used (in fuels, products, food or cosmetics).

\section{Recommendations}

Research that aims to increase the contribution made by biobased materials to the circular economy should focus more on:

- assessing the options for producing sustainable raw materials (more residual waste streams, more intensive land use and more recycling of fossil plastics);

- a comprehensive assessment of the sustainable use of biomass when selecting applications. 


\section{$1 \quad$ Inleiding}

\section{$1.1 \quad$ Aanleiding}

Het stimuleren van de productie van biobased producten vormt een uitdaging voor de circulaire economie en voor beleid gericht op het behoud van natuurlijk kapitaal. Het vraagt daarnaast meer inzicht in de relatie tussen biobased materialen, grondstoffen en landgebruik. Biobased materialen zijn (deels) gemaakt van plantaardige biomassa zoals zetmeel, suiker, cellulose, melkzuur en eiwitten. Toepassingen van biomassa in biobased plastics, vezels en oplosmiddelen zijn belangrijk voor de circulaire economie waarin men minder fossiele grondstoffen als kolen, olie en aardgas wil gebruiken om de opwarming van het klimaat te beperken. De rol van plantaardige biomassa in de circulaire economie betreft zowel de grondstof als haar bijdrage aan het materiaal dat biologisch afbreekbaar is of kan worden hergebruikt.

Het streefbeeld van de rijksoverheid is dat in 2030 het aandeel fossiele grondstoffen in de Nederlandse economie is teruggebracht tot $70 \%$ van het totale grondstofgebruik en dat het aandeel biomassa stijgt naar 30\% (EZ, 2015). De rijksoverheid wil deze transitie naar een circulaire economie stimuleren en onderscheidt vijf transitieagenda's waaronder een voor kunststoffen (IenM \& EZ, 2016). Op verzoek van het Planbureau voor de Leefomgeving (PBL) zal Wageningen Economic Research zich in deze studie richten op de bijdrage van biobased plastics om fossiele plastics in Nederland te vervangen. Om een idee te geven van de bijdrage van biobased plastics wereldwijd: op dit moment levert biobased plastics één tot twee procent van de 300 miljoen ton jaarlijks geproduceerde kunststof. Nu bestaat $86 \%$ van het kunststof uit nieuwe fossiele grondstoffen (ruwe olie en gas) en wordt slechts 14\% gerecycled (Ellen MacArthur Foundation, 2017).

\section{Biobased economie}

Biomassa kan in de bioeconomie niet alleen worden ingezet voor materialen en brandstoffen, maar ook voor voedsel en veevoer. De biobased economie richt zich hierbij op de non-food toepassingen van biomassa (mais, biet, suikerriet, hout, aardappel en algen) in materialen en brandstoffen. Figuur 1.1 toont de samenhang tussen het gebruik van biomassa in de biobased economie en de stappen tot hergebruik in circulaire economie. De chemische industrie geeft aan dat in Europa maximaal $70 \%$ van de grondstoffen kunnen worden hergebruikt. Voor een overgang naar een circulaire economie is dus nog een flink tekort aan grondstoffen waarvoor biomassa nodig is. Dit maakt de biobased economie onmisbaar voor de circulaire economie.

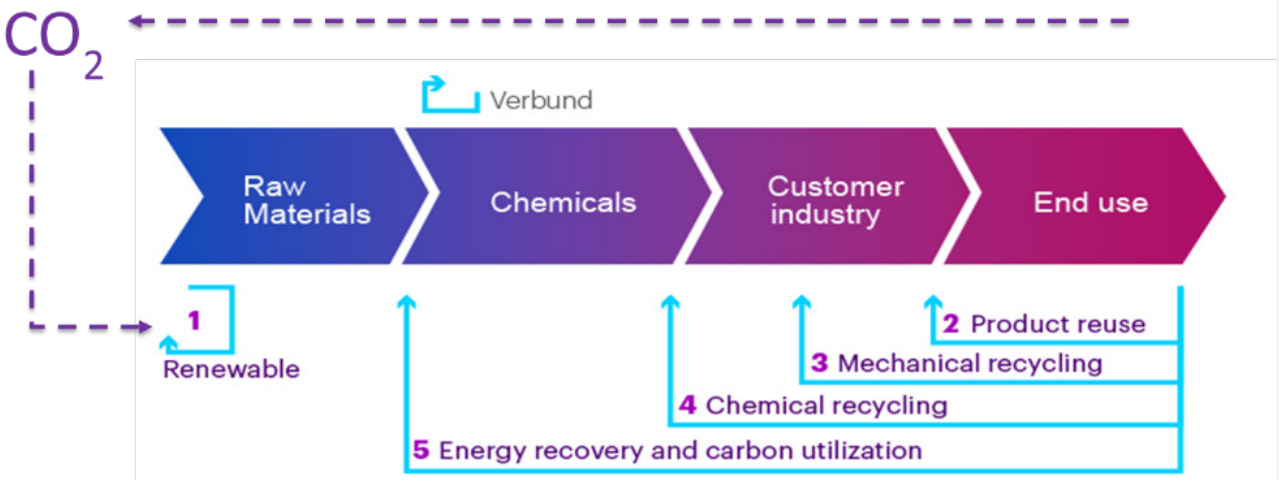

up to $10 \%$ of the European chemical industry molecules can be recirculated using all five loops.

Figuur 1.1 Bijdrage hergebruik van grondstoffen aan circulaire economie. Bron: Accenture, 2017; bewerking BBD, 2017 
Elk van de vijf loupes heeft zijn eigen vereisten (Accenture, 2017). Zo vraagt de vervanging van fossiele grondstoffen door biomassa als eerste stap (Renewable), om de resterende $30 \%$ aan grondstoffen te realiseren, investeringen in de grondstofinfrastructuur, conversietechnologie en meer landgebruik. In de tweede stap (Product reuse) wil men nieuwe producten en oplossingen ontwikkelen die hergebruikt kunnen worden, zoals petflessen. Voor mechanische recycling als derde stap (Mechanical recycling) kunnen end-user materialen worden verzameld, verwerkt en opnieuw ingebracht in de waardeketen zonder hun chemische samenstelling te wijzigen, zoals de recycling van thermoplastics en de extractie van fosfor uit slib. Deze derde stap wordt als een belangrijke strategie voor de toekomst gezien (CE Delft, 2017). De vierde stap (Chemical recycling) en de vijfde stap (Energy recovery) vragen nog onderzoek.

In deze voorstudie verkennen we vooral de eerste stap, de vervanging van fossiele grondstoffen door biomassa. De rol van biomassa bij de vraag naar land is daarbij afhankelijk van de toepassing van de biomassa. Zo is de huidige vraag naar land voor biobased materialen veel minder groot dan die voor voedsel. In land uitgedrukt gaat wereldwijd ongeveer 40 miljoen km² naar vlees en zuivel, 12 miljoen $\mathrm{km}^{2}$ naar plantaardig voedsel en 0,3 miljoen $\mathrm{km}^{2}$ naar biobrandstoffen. In 2014 werd circa $6.800 \mathrm{~km}^{2}$ gebruikt voor biobased plastics (www.european-bioplastics.org). Daarbij strekt het landgebruik voor het telen van biomassa dat in Nederland wordt verwerkt zich voor zowel voedsel als voor biobrandstoffen en biobased plastics, ver buiten de grenzen uit. Nederland importeert veel biomassa voor biobrandstoffen uit landen buiten Europa waar de productie ten koste kan gaan van het telen van voedselgewassen. De Europese Unie heeft daarom een richtlijn hernieuwbare energie opgesteld opdat producenten duurzame en verantwoorde biomassa leveren. Voor import naar Nederland mogen boeren geen biobrandstofgewassen verbouwen in gebieden met een grote biodiversiteit, zoals in een regenwoud of een beschermd natuurgebied, en niet in gebieden die veel $\mathrm{CO}_{2}$ vasthouden, zoals oerbossen, veengebieden en graslanden. Ook mogen zij hiervoor geen veengebieden ontwateren. Voor biobased materialen moeten deze eisen nog worden vastgesteld.

Biomassa is onmisbaar bij het vervangen van fossiele grondstoffen in een circulaire economie. Een belangrijke toepassing van biobased materialen zijn plastics voor verpakkingen en consumenten goederen. In Nederland wordt vooral de suikerbiet als toekomstige grondstof voor biobased plastics gezien (EZ, 2015). Veel bedrijven en sectoren in Nederland onderzoeken de mogelijkheid, en/of hebben de ambitie om op biobased materialen over te gaan (RVO, 2017). De vraag is dan hoeveel biomassa hiervoor nodig is, in hoeverre Nederland hier qua landbouwgrond in kan voorzien en de beoogde transitie naar een biobased en circulaire economie kan realiseren. Wageningen Economic Research verkent daarom in hoeverre biobased materialen in Nederland een bijdrage kunnen leveren aan de circulaire economie.

\subsection{Doelstelling, onderzoeksvragen en methode}

Het doel van dit onderzoek is om meer inzicht te krijgen in hoeverre fossiele grondstoffen in kunststoffen (plastics) door biomassa kunnen worden vervangen en of voor Nederland de gevraagde transitie naar duurzame biobased plastics kan worden gerealiseerd. Dit doel is uitgewerkt in de volgende vragen:

1. Hoe kan de relatie tussen het gebruik van biomassa in plastics, de bijdrage aan de circulaire economie en de impact op het landgebruik empirisch worden geduid en kan Nederland hier in voorzien?

2. Welke uitdagingen zijn er voor een transitie naar duurzame biobased plastics bij:

- het verkrijgen van biomassa uit Nederland of elders,

- de technologische innovatie en mogelijkheid tot hergebruik,

- de standaardisatie en duurzaamheidscriteria, en

- de vraag vanuit de markt?

\section{Methode}

1. Uit de CBS energiestatistiek kan worden berekend hoeveel Petajoule (PJ) de chemische industrie uit fossiele energiedragers verbruikt voor niet energetische doeleinden. Deze hoeveelheid PJ kan op basis van gemiddelde $\mathrm{PJ}$-inhoud van agrarische gewassen worden omgerekend naar de 
hoeveelheid biomassa en areaal gras- en akkerbouwland die nodig zou zijn om dit te telen. Op basis van literatuur wordt aangegeven welke toepassingen in de kunststoffensector met biomassa mogelijk zijn.

2. Literatuuronderzoek en interviews met vier deskundigen uit de wetenschap (Christiaan Bolck, Wageningen Food \& Biobased Research/FBR), biobased industrie (Rop Zoetemeyer, Stichting Biobased Delta/BBD), bepalen en beheer van normen (Harmen Willemse, NEN) en civil society (Jelmer Vierstra, Stichting Natuur \& Milieu/N\&M). Zij waarderen de bijdrage van de biobased economie aan de circulaire economie zowel positief als negatief. Wanneer uitspraken van geinterviewden in de tekst zijn opgenomen, wordt hierbij verwezen naar hun bedrijfsnaam. Wanneer achter de bedrijfsnaam ook het jartaal 2017 staat, betreft het echter en publicatie.

\subsection{Inhoud van dit rapport}

Het doel van dit project is vooral om de relatie tussen biobased plastics, circulaire economie en natuurlijk kapitaal te verkennen. De berekening van het benodigde landgebruik (als indicator voor natuurlijk kapitaal) is bedoeld als een vingeroefening om meer inzicht in de orde van grootte van de potentiële vraag naar plantaardige grondstoffen voor biobased plastics te krijgen. Zij is ook afhankelijk van aannames die wij waar mogelijk duidelijk maken. Immers, verander je de aannames dan verandert ook de uitkomst.

Het resultaat van deze verkenning is een technisch rapport dat input levert voor het PBL-programma over de circulaire economieën voor PBL's wettelijke taken. In Hoofdstuk 2 beschrijven we de toepassingen van biomassa in plastics en de impact van het vervangen van fossiele grondstoffen door biomassa op het natuurlijk kapitaal en milieu. Hoofdstuk 3 verkent de problemen en kansen voor de transitie naar duurzame biomassa in biobased plastics. Hoofdstuk 4 rondt af met conclusies en thema's voor verder onderzoek. 



\section{Biomassa in plastics}

\section{$2.1 \quad$ Inleiding}

In dit hoofdstuk richten wij ons op het beantwoorden van de eerste vraag naar het empirisch duiden van de relatie tussen het gebruik van biomassa in biobased plastics, de bijdrage aan de circulaire economie en de impact op het natuurlijk kapitaal. Meer concreet gaat het om vragen als in hoeverre toepassingen in biobased plastics bijdragen aan een circulaire economie en wat de potentie is van het landgebruik in Nederland voor het telen van biomassa. Daarvoor onderscheiden en bespreken wij in par. 2.2 een aantal toepassingen van biobased plastics. Daarna berekenen wij in par. 2.3 in hoeverre het Nederlandse landgebruik kan voorzien in de behoefte aan biomassa voor kunststoffen (plastics) en gaan wij in op de externe impacts (par. 2.4).

\subsection{Toepassingen van biobased plastics in een circulaire economie}

Net als fossiele plastics zijn biobased plastics bruikbaar voor vele toepassingen met een breed scala aan eigenschappen. Om het gebruik van biomassa in biobased plastics te duiden, starten we met een overzicht van de belangrijkste toepassingen. Figuur 2.1 toont dat verpakkingen de meest voorkomende toepassing zijn, gevolgd door consumentengoederen en toepassingen in de auto- en transportsector. Een kanttekening bij figuur 2.1 is dat de term 'bioplastic' ruimer is dan 'biobased plastic' - waar deze voorstudie zich op richt - en ook een klein deel fossiele polymeren bevat dat kan worden gecomposteerd, zij het op een industriële wijze. Dit deel is klein (qua volume) en nemen wij niet mee bij het verkennen van de rol van biomassa in biobased plastics.

\section{Global production capacities of bioplastics in 2016 (by market segment)}

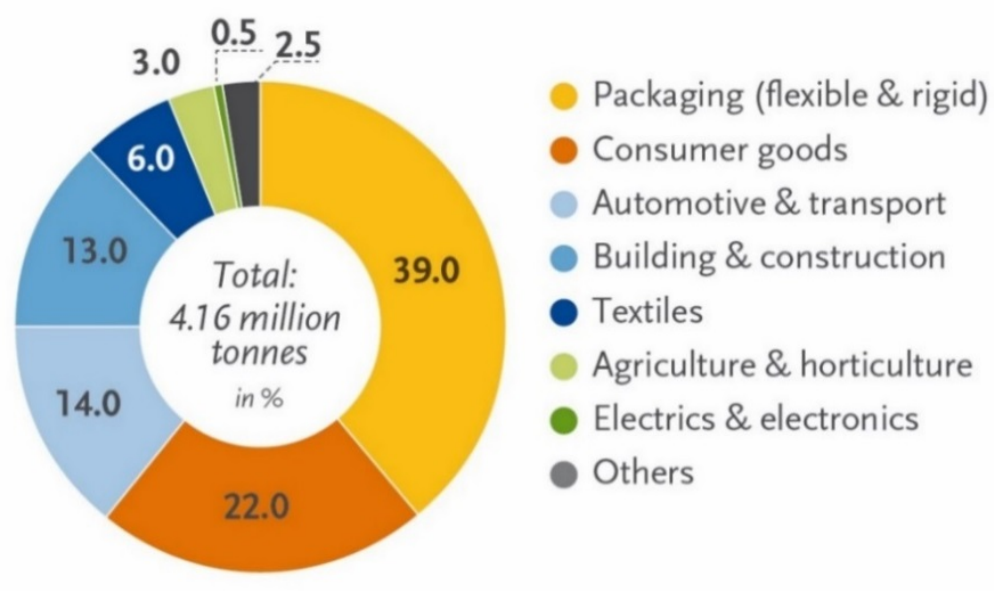

Source: European Bioplastics, nova-Institute (2016). More information: www.bio-based.eu/markets and www.european-bioplastics.org/market

Figuur 2.1 Productiecapaciteit voor toepassingen van (bio)polymeren in bioplastics 


\section{Biobased plastics en bioplastics}

De verwarring tussen de termen 'biobased plastic' en 'bioplastic' kan worden opgehelderd door de definitie van het gebruik van biomassa en afbreekbaarheid als twee verschillende eigenschappen toe te lichten:

- Biobased plastics zijn volgens de Europese norm (EN16575) gedefinieerd als producten die geheel of gedeeltelijk zijn gemaakt uit biomassa. Een biobased product wordt gekarakteriseerd door zijn biobased koolstofgehalte (CEN/TS 16640), of het biobasedgehalte koolstof, waterstof, stikstof en zuurstof (EN 16785-1). De genoemde normen zijn Europese normen die aangeven hoe deze aandelen te meten zijn. Het Nederlandse Normalisatie Instituut (NEN) beheert een certificeringssysteem (www.biobasedcontent.eu) om het biobasedgehalte op basis van de norm EN 16785-1 onafhankelijk te meten.

- Fossiele en biobased plastics die volgens de Europese norm voor industriele compostering zijn gecertificeerd (EN 13432 voor verpakkingen en EN 14995 voor producten) en dus afbreekbaar zijn.

In figuur 2.2 worden beide eigenschappen gecombineerd. Zo zijn er:

- Linksboven: biobased plastics van (deels) biomassa die niet afbreken in het milieu.

- Rechtsboven: biobased plastics van (deels) biomassa die wel afbreken in het milieu.

- Rechtsonder: plastics van fossiele grondstoffen die ook afbreken in het milieu.

- Linksonder: plastics van fossiele grondstoffen die niet afbreken in het milieu.

Bioplastics bevat dus niet alleen de biobased plastics op de bovenste rij links en rechts, maar ook de kleine groep fossiele plastics rechtsonder. Gezien de focus van het onderzoek op biomassa, richten wij ons in het vervolg op de bovenste rij uit figuur 2.2, dus alleen op biobased plastics die wel of niet afbreekbaar zijn.

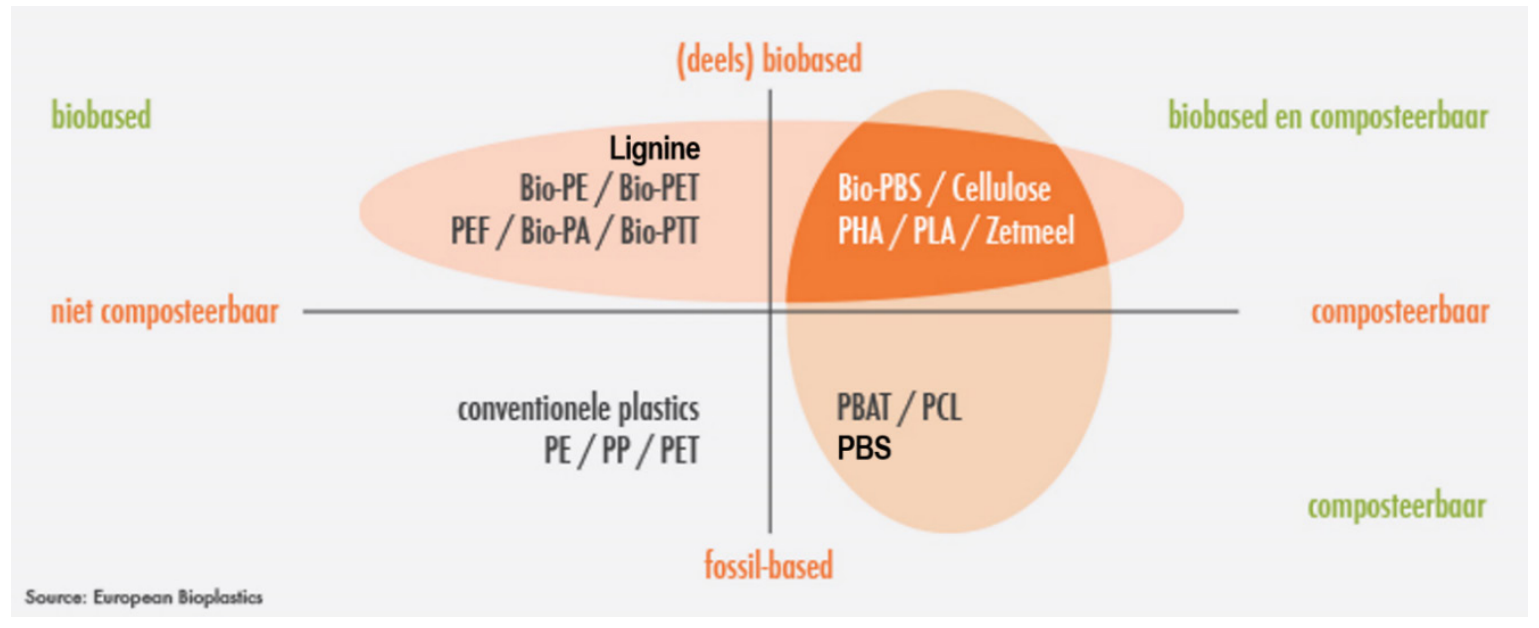

Figuur 2.2 Plastics onderscheiden naar gebruik (bio)polymeren en composterbaarheid.

\section{Afbreekbaar en herbruikbaar}

Ook de begrippen 'composteerbaar/ afbreekbaar' en 'recyclebaar/herbruikbaar' verschillen van elkaar. Als het biobased plastic namelijk volgens de Europese norm voor industriele compostering biologisch afbreekbaar is, betekent dat nog niet dat het direct in de natuur afbreekbaar is. Daarvoor moet het plastic namelijk eerst een industriele compostering ondergaan (zie hiervoor EN 13432/14995). Daarbij maakt ook het milieu (land of water, koud of warm) verschil en betekent biodegredable niet automatisch dat het sne/ uit het milieu verdwijnt. Volgens de geïnterviewde van de NEN mag dit bij verpakkingen hooguit zes weken tijd kosten. De geïnterviewde van BBD vindt afbreekbaarheid op zichzelf weinig zeggen als niet naar de functie wordt gekeken. Biobased verpakkingen voor eenmalig gebruik moeten zo snel mogelijk zijn afgebroken. Een pin in je lichaam - na bijvoorbeeld een botbreuk - doet er twee jaar over (en bespaart daarmee wel een operatie). Soms is het zelfs beter als de biobased materialen helemaal niet afbreekbaar zijn zoals een fles water.

De niet-afbreekbare biobased plastics (linksboven) zijn mechanisch te recyclen als de stofstromen zuiver zijn en alleen uit polymeren bestaan. De biobased plastics zijn echter vaak een mengsel van verschillende polymeren met andere stoffen (lubricants) en daardoor niet 100 procent zuiver te 
scheiden. ${ }^{1}$ De huidige afbreekbare biobased plastics (rechtsboven) hebben een te klein volume om uit het huishoudelijk afval te kunnen worden gescheiden. In grootverbruik, zoals het gebruik van bekers, borden en bestek bij festivals en stadions, zijn ze wel makkelijker te scheiden en te recyclen (CE Delft, 2017).

Combinatie van biobased materialen die wel of niet afbreekbaar leidt tot een aantal toepassingen die wij hieronder toelichten (www.groenegrondstoffen.nl).

\section{Biobased plastics: biobased niet afbreekbaar (figuur 2.2 - linksboven)}

Tot de niet afbreekbare biobased plastics en polymeren met een behoorlijke omvang horen bio-PET en bio-PE van suikerriet. Deze producten zijn goed te scheiden en dus wel ryclebaar. Beide zijn een 'dropin' wat betekent dat de biomassa chemisch identiek is aan het fossiel PE(T) en het materiaal dezelfde productie- en verwerkingstechnieken kan ondergaan. Toepassingen zitten onder andere in verpakkingen. CocaCola gebruikt haar bio-petfles. Supermarkten bieden bio-PE draagtassen herkenbaar aan het 'I'm Green'-logo. Ecover verpakt haar schoonmaakproducten in bio-PE flacons (Molenveld et al., 2014).

Veel drop-ins hebben per definitie weinig nieuwe eigenschappen ten opzichte van conventionele plastics. Ze moeten daarom op prijs concurreren met fossiele grondstoffen die goedkoop zijn zo lang de olieprijs en $\mathrm{CO}_{2}$-prijs laag is, of door het beleidsmatig ondersteunen van de import van biomassa. Een andere optie is om bereidheid te vinden bij het publiek om extra te betalen voor deze groene materialen als er extra functies zijn. Zolang beide opties niet lukken, zijn drop-in chemicaliën een wankele basis voor verdere ontwikkeling (Carus et al., 2016). Wel kansrijk zijn bioplastics die een unieke functionaliteit bieden, zoals biobased PEF (Polyethylene Furanoate) dat minder koolzuur uit een fles laat ontsnappen dan de fossiel-based PET en zo meer op glas lijkt (Didde, 2017). Biobased Delta (2017) wil onderzoek naar nieuwe producten stimuleren dat in plaats van de fossiele producten na te bootsen, zich meer richt op de functionaliteiten op basis van de eigenschappen van de gebruikte biomassa (zoals de structuur, gewicht en doorlaatbaarheid).

\section{Biobased plastics: biobased en afbreekbaar (figuur 2.2 - rechtsboven)}

Polymelkzuur (PLA, polylactic acid) is een veel voorkomend afbreekbaar biobased plastic gemaakt van suikers uit suikerbiet, suikerriet en mais en in de toekomst ook uit agrarische reststromen (zoals melkwei, maïskolven en stro). PLA wordt gebruikt in (voedsel)verpakkingen zoals plastic bakjes, folies en foam (piepschuim). PLA kenmerkt zich door transparantie en waterbestendigheid en is afhankelijk van de inhoud geschikt als verpakkingsmateriaal voor snoep, groente, fruit, koude dranken/ijs, vlees en zuivel. Als vezel wordt PLA gebruikt in matrassen omdat het goed vocht reguleert, voor de vulling van dekbedden en voor kleding en tapijt. PLA wordt ook gebruikt in medische toepassingen zoals hechtdraad en botplaten. De meeste melkzuren zijn binnen enkele weken afgebroken (uitgezonderd Poly-L-melkzuur). Tot de afbreekbare plastics hoort ook Bio-PBS (bio-barnsteenzuur), een natuurlijke vezelcomposiet voor auto-interieurs en in de toekomst mogelijk ook voor deurpanelen, sierstrips en verpakkingsmaterialen voor kaas en vlees. Deze breken af in specifieke milieu's.

Vaak zijn biobased en afbreekbare plastics duurder dan fossiele plastics. Specifieke materiaaleigenschappen kunnen echter een materiaal- of kostenbesparing mogelijk maken (Van den Oever et al., 2017). Zo kan PLA dat waterdamp makkelijk doorlaat een voordeel zijn bij een 'ademende' verpakking voor groente of fruit als dit tot een langere houdbaarheid leidt en waar de consument extra voor wil betalen (Didde, 2017). Land- en tuinbouwplastic van PLA kan met ander afbreekbaar agrarisch afval worden gecomposteerd. Ook blijkt PLA in combinatie met natuurlijke vezels (ook wel biocomposieten genoemd) biologisch snel afbreekbare resultaten op te leveren, zoals bij het gebruik van bloempotten en Mars-wikkels om chocoladerepen (BBD).

Een overzicht van de belangrijkste materialen en toepassingen van biobased plastics is terug te vinden in figuur 2.3 .

\footnotetext{
${ }^{1}$ Fossiele plastics zoals petflessen (linksonder) zijn ook te scheiden en mechanisch te recyclen als de stofstromen zuiver zijn en alleen uit polymeren bestaan.
} 


\section{PACKAGING}

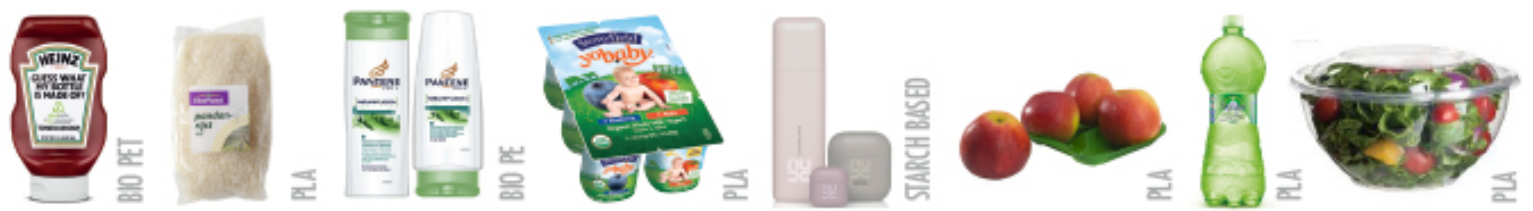

\section{DISPOSABLES}
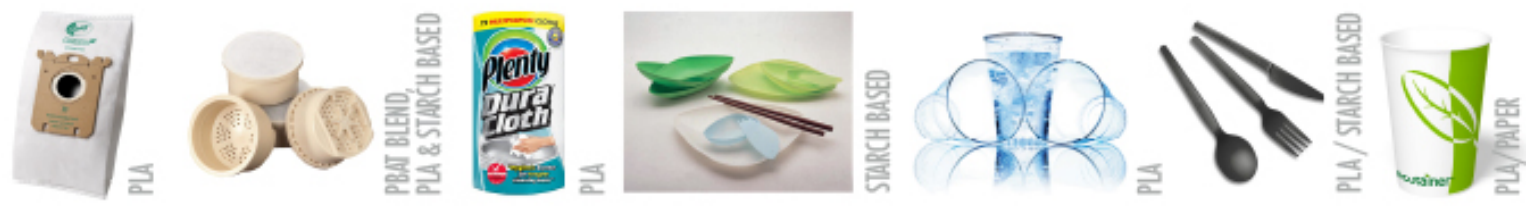

\section{FILMS}

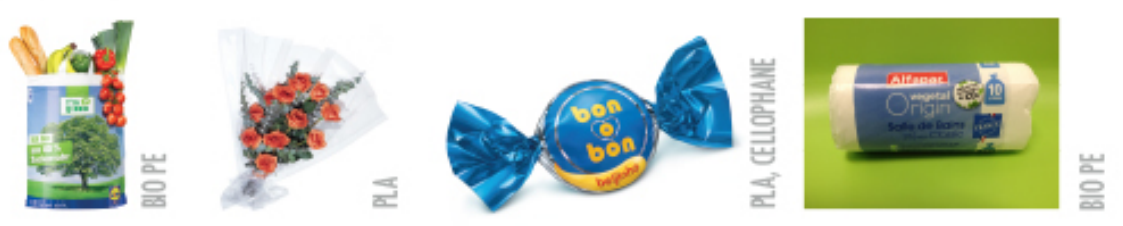

\section{CONSUMER GOODS / DURABLES}
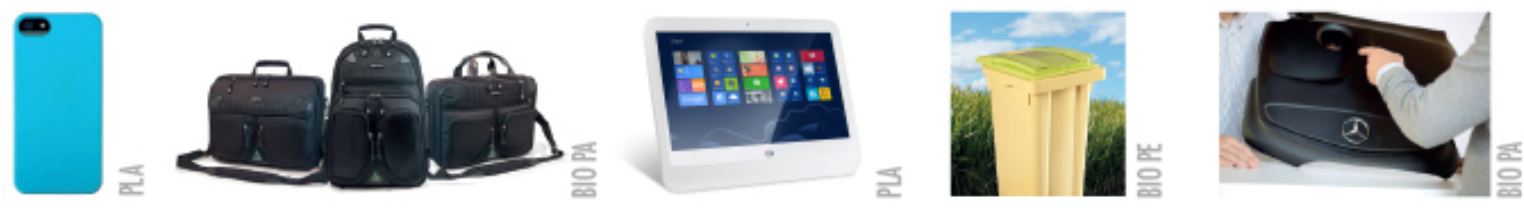

Figuur 2.3 Toepassingen van biobased plastics en gebruikte biobased materialen. Bron: www.groenegrondstoffen.nl

\section{Biobased plastics wereldwijd}

Naar verwachting groeit de wereldwijde productie van biobased plastics van 4,2 miljoen ton in 2016 naar 6,1 miljoen ton in 2021 (zie figuur 2.4). De markt wordt gedomineerd door biobased plastics die niet afbreekbaar zijn (figuur 2.4: oranje en figuur 2.2 linksboven). Maar een klein deel van de biobased plastics is afbreekbaar (figuur 2.4: groen en figuur 2.2 rechtsboven).

Naar verwachting zal de jaarlijkse stijging van de vraag naar fosiel- en bio-based plastics (ieder ruim $5 \%$ ) doorgaan. Redenen waarom de vraag naar biobased plastics zal groeien, zijn volgens een geïnterviewde de substitutie van metaal door plastic wat een veel lichter product oplevert en het vervangen van duurdere petrochemicalieën door goedkopere suiker om melkzuur te maken (BBD). Hoewel de hoeveelheid biomassa in de chemische en plasticindustrie groeit, is deze toename veel minder dan die voor biobrandstoffen die kunnen profiteren van de RED en ETS regelingen om meer houtpellets te importeren (Carus et al., 2016).

Hoewel het gebruik van biomassa voor plastics nu nog klein is, zal het wel toenemen. Zo is per kilo geproduceerd plastic meer biomassa nodig dan er olie of gas nodig zou zijn (CPB, 2017). Bij kunststof uit fossiele grondstof ligt de gewichtsverhouding rond de één, maar voor de productie van bijvoorbeeld PLA voor biobased plastics is 1,5 maal de biomassa nodig (WPI, 2009). 


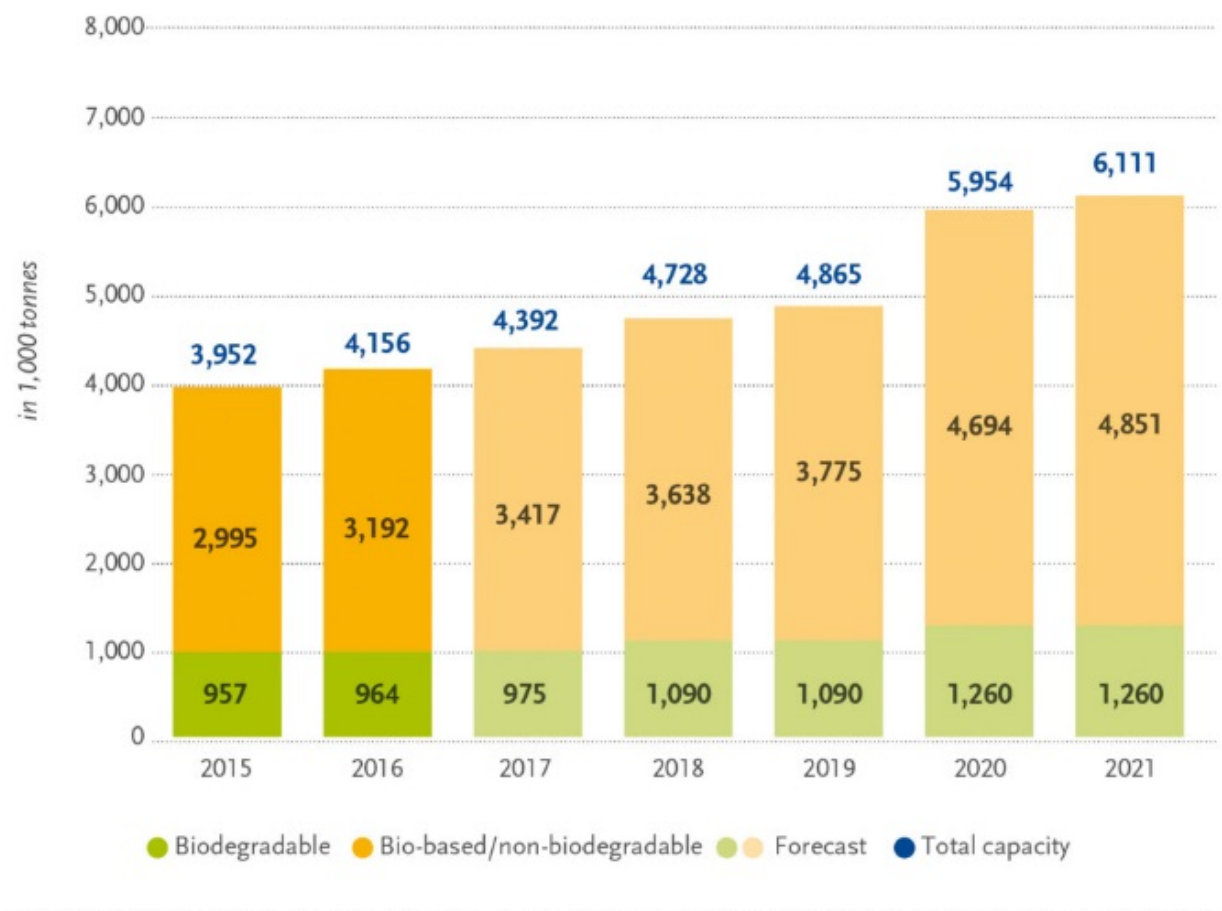

Source: European Bioplastics, nova-Institute (2016)

More information: www.bio-based.eu/markets and www.european-bioplastics.org/market

Figuur 2.4 Ontwikkeling productie biobased plastics 2015-2021

De toenemende vraag naar biomassa zal leiden tot meer landgebruik. Om bijvoorbeeld in de Verenigde Staten de vraag naar plastic te vervangen door biobased plastics (PLA) is een kwart van de wereldwijde maïs- of rijstoogst, de helft van het suikerriet of 5,5 keer de wereldproductie van aardappelen nodig (WPI, 2009). Deze grove gedachtenexercitie toont dat veel land nodig is bij een omschakeling naar biobased materialen. De ramingen van de geproduceerde biomassa in Nederland lopen uiteen, maar hebben gemeen dat het potentieel aan biomassa beperkt is en grotendeels geïmporteerd zal moeten worden (PBL, 2014).

\subsection{Landbouwgrond in Nederland om biomassa te telen}

Om meer inzicht te krijgen hoeveel biomassa in Nederland moet worden geteeld voor biobased plastics, berekenen we hoeveel hectare ongeveer nodig zou zijn om de binnenlandse vraag naar fossiele plastics te vervangen (figuur 2.2 links- en rechtsboven). We willen als gedachte-experiment de orde van grootte van het benodigde landgebruik bepalen.

Volgens het CBS (2017) was het verbruik van de chemie (niet energetisch) in 2016 in totaal 553 PJ (Petajoule). Wij hebben dit getal als uitgangspunt genomen voor de hoeveelheid benodigde biomassa en hebben geen rekening gehouden met de grondstoffen waaruit dit getal is opgebouwd.

In Nederland bestaat het huidige areaal natuur- en cultuurgrond uit 1.963 .630 hectare (CBS, 2017). Daarvan is het areaal cultuurgrond 1.789 .610 hectare. Het areaal natuurgrond (167.360 ha) blijft verder buiten beschouwing. De 1.789.610 hectare cultuurgrond bestaat uit 509.060 hectare akkerbouw en 1.177.940 hectare grasland en voedergewassen, de rest is tuinbouw. Op de cultuurgrond worden verschillende C-dragende gewassen verbouwd zoals suikerbieten, zetmeelaardappelen, mais en gras. 
Daarvan is per gewas een inschatting gemaakt van de hoeveelheid droge stof per hectare en is aangenomen volgens Sanders (2014) dat elke ton droge stof 15 GJ (Gigajoule) aan gemiddelde energie-inhoud bevat. ${ }^{2}$ In de commissie Corbey (2014) kwam men op basis van Rabou et al. (2006) tot $17 \mathrm{GJ}$. Tabel 2.1 maakt duidelijk dat er ongewogen gemiddeld 214 (Sanders) en 242 (Rabou et al.) GJ per hectare aan biomassa te realiseren is. Deze ongewogen getallen houden dus geen rekening met de bestaande oppervlaktes van de gewassen. Aangezien er veel meer gras dan een kwart van het gemiddelde is en veel minder suikerbieten, betekent dit dat de gemiddelde energie-inhoud per hectare in de praktijk lager zal zijn dan hier vermeld.

Tabel 2.1 Gewassen naar droge stof en gemiddelde energie-inhoud per hectare

\begin{tabular}{lccc} 
Gewassen & $\begin{array}{c}\text { Droge stof } \\
\text { (ton/ha) }\end{array}$ & $\begin{array}{c}\text { Energie (GJ/ha) } \\
\text { volgens Sanders }\end{array}$ & $\begin{array}{c}\text { Energie (GJ/ha) } \\
\text { volgens Rabou et al. } \\
(2006)\end{array}$ \\
\hline Suikerbieten & 20 & 300 & 340 \\
\hline Zetmeelaardappelen & 12 & 180 & 204 \\
\hline Mais & 15 & 225 & 255 \\
\hline Gras & 10 & 150 & 170 \\
\hline Gemiddeld ongewogen & & 214 & 242 \\
\hline
\end{tabular}

Het totale aanbod aan hectares cultuurgrond $1.789 .610 \times$ de berekende gemiddelde energie-inhoud van 214 tot $242 \mathrm{GJ}$ per hectare (Sanders versus Rabou) levert 382,5 tot 433,5 PJ energie uit biomassa. Ten opzichte van het benodigde niet-energetische verbruik in de chemie van 553 PJ, betekent dit dus een tekort van 170 tot $119 \mathrm{PJ}$. In de praktijk zullen de tekorten echter groter zijn, omdat er naar verhouding meer gras en minder suikerbieten worden geteeld. Zouden we echter alle cultuurgrond volpoten met suikerbieten, dan kan de chemische industrie bijna van voldoende biomassa worden voorzien $(1.789 .610 \times 300=537 \mathrm{PJ})$.

'Nederland bietenland' als schrikbeeld gaat alleen in berekeningen op. Volgens de chemische industrie valt niet op korte termijn te verwachten dat de berekende energie-inhoud qua technologische ontwikkeling haalbaar is. De ontwikkeling naar het gebruik van meer biomassa in de circulaire economie vereist meer investeringen in de nieuwe grondstof infrastructuur en conversie technologie (BBD). De branchevereniging van de chemische industrie in Nederland (VNCI) heeft op basis van eigen schattingen over de mogelijke technologische innovatie voor de Nederlandse industrie de ambitie uitgesproken dat zij in $203043,5 \mathrm{PJ}$ aan fossiele grondstoffen kan vervangen door biomassa (EZ, 2015, p. 29). Dat is dus maar $8 \%$ van het benodigde niet-energetische verbruik in de chemie. ${ }^{3}$

Wanneer het telen van suikerbieten in deze behoefte aan biomassa voor de chemische industrie zou voorzien, dan zou dit bijvoorbeeld volgens Sanders 145.000 hectare (43,5 miljoen/300) vragen. Aangezien in 2017 op ruim 85.000 hectare suikerbieten wordt geteeld (CBS, 2017) zou dat nog een flinke stijging van het areaal betekenen. Andere oplossingen zijn meer gebruik van zetmeel en suikerhoudende reststromen uit de voedselverwerkende industrie, residuen uit de land- en bosbouw, een intensiever landgebruik of meer hergebruik van plastics.

\footnotetext{
21 Petajoule $=1$ miljoen Gigajoule en komt overeen met 31,6 miljoen $\mathrm{m}^{3}$ aardgas.

3 Ter vergelijking: de vraag naar biomassa voor transportbrandstoffen wordt ingeschat in 2030 op 34 PJ, zie: Biomassa 2030 | Rapport | Rijksoverheid.nl.
} 


\subsection{Externe impacts van biomassa op natur en milieu}

\section{Indirect Land Use Change (ILUC)}

De genoemde oplossingen in Nederland leiden tot de vraag welke veranderingen in het landgebruik elders door het telen van biomassa voor biobased toepassingen (plastics, vezels en oplosmiddelen) ontstaan (Bolck et al., 2012). Bodems met een hoog koolstofgehalte, zoals regenwouden of natuurlijke prairies, zullen veel meer $\mathrm{CO}_{2}$ afgeven aan de atmosfeer wanneer ze in gebruik worden genomen voor akkerbouw. Dit kan een direct mechanisme zijn, maar het kan ook een indirect mechanisme zijn, waarbij het verbouwen van plantaardige grondstof voor biobased materialen in plaats van voor voedsel leidt tot het gebruik van nieuwe gronden voor voedselproductie elders. Dit mechanisme wordt aangeduid als Indirect Land Use Change (ILUC). ILUC kan leiden tot de conversie van natuurlijke vegetatie en daardoor tot een afname van de biodiversiteit en tot meer $\mathrm{CO}_{2}$-emissies door afname van koolstof die is vastgelegd in de natuurlijke vegetatie. Het schatten van deze ILUC-effecten blijkt echter lastig na analyse van studies over de impact van het gebruik van biomassa voor biobrandstoffen (Woltjer et al., 2017).

Op basis van de literatuur komen de auteurs tot vijf mitigatiestrategieën om een negatieve ILUC door het telen van biomassa van biobrandstoffen te vermijden (Woltjer et al., 2017). Deze gelden in principe ook voor biobased materialen:

1. Gebruik van agrarische residuen en afval.

2. Gebruik van grond dat ongeschikt is voor het verbouwen van voedsel zoals marginale gronden.

3. Meer efficiëntie in de voedselketen.

4. Beschermen van gebieden met een hoog koolstofgehalte en rijkdom aan biodiversiteit.

5. Certificeren van maatregelen die de hiervoor genoemde mitigatiestrategieën (2. en 3.) beogen.

Voor biobased materialen zijn de ILUC-effecten niet bekend, maar kunnen wel relaties worden verkend. Zo is het gebruik van agrarische residuen en afval in biobased toepassingen (tweede generatie grondstoffen) nog beperkt en zijn er voor biobased plastics geen voorbeelden van producten bekend die hierop zijn gebaseerd. Het reactiveren van marginale gronden (braakligging en verwoestijning) om biomassa voor biochemicalien te telen, gebeurt nu in Zuid-Europa. Een voorbeeld is de bioraffinage van distels op marginale, relatief onvruchtbare akkers op Noord-Sardinië met hoge opbrengsten aan lignocellulose en aan zaden met hoge oliegehaltes zonder veel bewatering (www.novamont.com). Veel regio's in Oost- en Zuid-Europa zijn net begonnen aan de ontwikkeling naar een biobased economie (Spatial Foresight et al., 2017). In Oost-Europa kan verbetering van de productie op de huidige landbouwgrond bijdragen aan het beantwoorden van de toenemende vraag naar biomassa. Voor het beschermen van gebieden met een hoog koolstofgehalte en rijkdom aan biodiversiteit zijn importrestricties opgesteld. Certificering van ILUC wordt in het volgende hoofdstuk besproken.

\section{Minder $\mathrm{CO}_{2}$-uitstoot}

Biobased plastic (figuur 2.2 links- en rechtsboven) wordt gezien als een duurzaam alternatief voor fossiel geproduceerd plastic, want de uitstoot van $\mathrm{CO}_{2}$ is vaak lager dan die van vergelijkbare fossielbased producten. Uit de levenscyclusanalyses (LCA) blijkt dat het type biobased materiaal (PLA, BioPET en Bio-PE) de meeste invloed heeft op de reductie van $\mathrm{CO}_{2}$, gevolgd door het type biomassa dat wordt gebruikt (suikers leveren meer reductie dan zetmeel) en de plaats van telen (CPB, 2017). Cruciaal voor het LCA-resultaat is ook de end-of-life fase en de omgang met koolstofopslag in biobased materialen.

\section{Overige externe impacts}

Naast minder $\mathrm{CO}_{2}$-uitstoot en mogelijke ILUC spelen er andere externe effecten die met elkaar moeten worden afgewogen om bio- en fossiel-based plastics goed te kunen vergelijken. Biobased producten met nieuwe biomassa hebben bijvoorbeeld - door bemesting - een grotere impact op eutrofiëring en verzuring in vergelijking tot fossiel-based producten (Van den Oever et al., 2017). Verder komt bij het gebruik van kunstmest $\mathrm{N}_{2} \mathrm{O}$ (lachgas) vrij wier broeikaseffect bijna 300 maal zo groot is als van $\mathrm{CO}_{2}$. Ook vragen de grondstoffen meer water. Dan wordt het op voorhand minder duidelijk in hoeverre biobased plastics duurzamer zijn dan hun fossiele equivalenten. Om hier echter uitspraken over te doen, is het belangrijk om de externe effecten met elkaar kwantitatief af te wegen. 


\section{$3 \quad$ Naar duurzame biobased plastics}

\section{$3.1 \quad$ Introductie}

In dit hoofdstuk bespreken wij een aantal ontwikkelingen die de transitie naar het gebruik van duurzame biomassa in biobased plastics bepalen. Het gaat hierbij om de toegevoegde waarde van biomassa (par. 3.2), technologische innovatie en mogelijkheid tot hergebruik (par. 3.3), standaardisatie en certificering van duurzaamheidscriteria (par. 3.4) en de vraag vanuit de markt (par. 3.5).

\subsection{Toegevoegde waarde van biomassa}

Bij de toegevoegde waarde van biomassa gaat het om de vraag waar deze voor moet worden ingezet. Naast input voor biobrandstoffen en materialen, is het telen van biomassa ook nodig voor veevoer en voedsel en farmacie. De vraag is hoe deze concurrentie om biomassa voor toepassingen moet worden beoordeeld. Gegeven de hoeveelheid biomassa dat nodig is om plastics te realiseren, is het de vraag in hoeverre dit beschikbaar is in Nederland (zie par. 2.3). Natuur \& Milieu heeft ook behoorlijke reserves bij de (grootschalige) inzet van biomassa als grondstof voor plastics, want zij vindt de beschikbaarheid van landbouwgrond te beperkt om die voor andere dan voedseltoepassingen in te zetten.

Om biobased plastics is in plaats van primaire productie te maken, is ook het gebruik van reststromen mogelijk (grijs zetmeel, FBR). Het gebruik van reststromen voor biobased producten (tweede generatie grondstoffen) waaronder plastics staat nu nog in de kinderschoenen. De huidige Europese afvalwetgeving werkt nu belemmerend voor het gebruik van reststromen, want grondstoffen hebben vaak de afvalstatus en kunnen dan niet als grondstof worden verhandeld en worden hergebruikt voor materialen (Rood \& Hanemaaijer, 2014). De geïnterviewde onderzoeker van FBR zou een versoepeling van de afvalwetgeving adviseren om de hele plant, inclusief reststromen, in te kunnen zetten. Daarbij willen de geinterviewden van de NEN en Natuur \& Milieu afval zo hoogwaardig mogelijk hergebruiken. Dat leidt tot projecten, zoals hergebruik van riet uit natuurgebieden voor plaatmateriaal (FBR). Hergebruik is echter niet eenvoudig, want de grondstoffen zijn vaak onzuiver en de productie vraagt meer energie dan haar fossiele equivalent (FBR).

Een vraag die samenhangt met de concurrentie om biomassa is in hoeverre het verwaarden ervan voor biobased plastics ten opzichte van andere toepassingsmogelijkheden voldoende duurzaam rendement oplevert hier en elders in Europa. Naast het duurzaam telen van suikerbieten is ook het telen van hout en riet relevant. Bij het gebruik van biomassa voor een toepassing moet men ook naar de energie-inhoud kijken. Aangezien die per $1 \mathrm{~kg}$ suiker, hout en lignine (ruim) de helft lager is dan die per $1 \mathrm{~kg}$ gas en olie, is het onverstandig om eerstgenoemden als (bijstook in) brandstof te nemen. Het belichten van praktijkvoorbeelden van ongewenste concurrentie tussen biomassastromen kan helpen de duurzaamheid van toepassingen van biomassa beter te waarderen (Brinkmann, 2014).

Tot nu toe is er in de literatuur vooral aandacht voor de economisch toegevoegde waarde van de biobased economie, maar ontbreekt inzicht in de sociale aspecten, zoals de leefbaarheid en werkgelegenheid in dunbevolkte gebieden, en in de milieuaspecten, zoals de bodemkwaliteit, het landgebruik en de klimaatwinst (zie Hfdst. 2). Ook de mogelijkheid tot hergebruik ontbreekt. Natuur \& Milieu (2017) zou daarom de bodemvruchtbaarheid als voorwaarde willen opnemen in de afweging waarvoor biomassa moet worden gebruikt en ook de kans op cascadering willen meewegen. Biobased Delta wil ook meer aandacht voor cascadering en wil het gebruik van meer biomassa breder zien dan alleen suikers, zetmeel en oliën (eerste generatie grondstoffen) en ook lignine in agroreststromen en hout (tweede generatie grondstoffen) meenemen. Het is daarom noodzakelijk om geavanceerdere modellen en concepten te ontwikkelen dan de gangbare gericht op toegevoegde economische waarde. 


\subsection{Ontwikkeling biobased plastics}

In Hoofdstuk 2 is aangegeven dat drop-in polymeren domineren in biobased plastics (figuur 2.2, linksboven) die weinig nieuwe of aanvullende eigenschappen bieden. Dit maakt drop-in polymeren een wankele basis voor verdere ontwikkeling (Carus et al., 2016). Vanuit de circulaire economie geredeneerd blijkt de toegevoegde waarde ook beperkt, omdat deze groep biobased polymeren niet afbreekbaar (maar wel recyclebaar) is. Biobased polymeren die wel afbreekbaar zijn vormen nog een klein aandeel (figuur 2.2, rechtsboven en figuur 2.4, groen).

Figuur 3.1 laat zien dat het ontwikkelen van een waardeketen voor biobased plastics lang is en veel actoren in het blauwe segment vraagt. De meeste aandacht gaat in het blauwe segment uit naar het samen ontwikkelen van halffabrikaten en het verbinden van actoren in de biobased industrie om de interne integratie te verbeteren. Verdere interne integratie met brand owners, retail en consumenten gebeurt stap voor stap evenals externe integratie met overheden (als launching customer), banken en ngo's. Zo hebben biobased industries pas recent meer contacten gelegd met brand owners als IKEA, LEGO en de voedingsindustrie.

BIOPLASTICS VALUE CHAIN

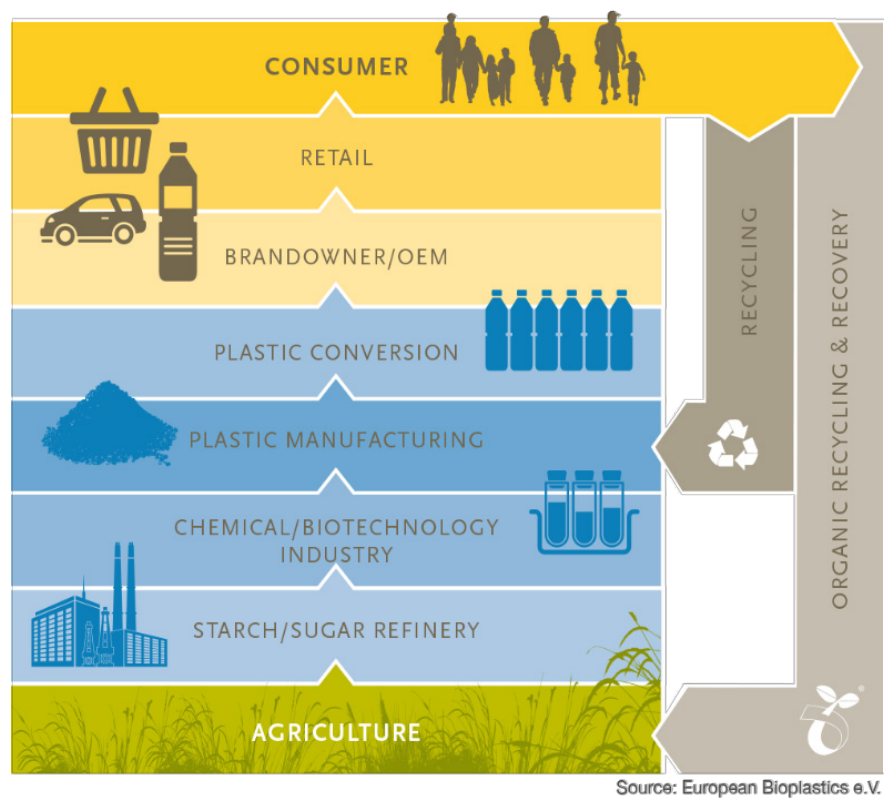

Figuur 3.2 Waardeketen van actoren voor biobased plastics

In Noordwest-Europa zijn de meeste regio's te vinden die voorop lopen in de biobased economie, waaronder ook de zuidelijke provincies in Nederland die horen tot Biobased Delta. Ook in de voorop lopende regio's is nog nauwelijks een waardeketen ontwikkeld die alle actoren van boer tot consument verbindt. Wel hebben deze regio's meer dan elders in Europa veel aandacht voor het blauwe segment ontwikkeld, bioraffinaarderijen opgezet en een samenwerking tussen landbouw en chemie tot stand gebracht.

Het ontwikkelen van een waardeketen geldt niet alleen voor biobased plastics, maar ook voor andere biobased materialen. Meer contacten met brand owners en consumenten kunnen bijdragen aan het vergroten van de maatschappelijke acceptatie van biobased producten en het opschalen. Daarnaast mag volgens meeste geinterviewden bij de overheid de noodzaak van een transitie naar een circulaire economie waar biobased onderdeel van is, sterker klinken (FBR, NEN, BBD). Biobased Delta (BBD) begon in 2011 met het verbinden van de landbouw en chemie in Zuidwest-Nederland en ondersteunt nu de transitie naar een circulaire economie. In haar bijdrage wil zij vaker expliciet de consequenties en inpasbaarheid van biobased ontwikkelingen in de circulaire economie benoemen (BBD, 2017). Zo wordt door de geïnterviewde gepleit om de 'total cost of ownership' van biobased afbreekbare producten te vergelijken met die van fossiele producten. De 'total cost of ownership' is het totaalbedrag aan kosten voor het bezit van een product gedurende de levenscyclus. Behalve de prijs om het product aan te schaffen omvat het ook de kosten van het moment van aankoop tot het moment van verwerking. 


\subsection{Standardisatie en certificering duurzaamheidscriteria}

\section{Criteria}

Er liggen kansen voor biobased materialen als de degradeerbaarheid van producten beter kan worden geduid (NEN) en Europees beleid op het gebied van duurzaamheidscriteria voor biobased producten zich verder ontwikkelt.

$\mathrm{Er}$ is wel een Europese norm waarin duurzaamheidsindicatoren voor biobased producten zijn gespecificeerd (EN 16751:2016). Hierin staan echter geen minimumeisen; dat is aan de politiek. Om vast te leggen of een biobased product ook duurzaam is, moeten in Europa een aantal minimumeisen worden vastgesteld waarmee dit wordt bepaald (grenswaarden). Wettelijke duurzaamheidseisen van biomassa voor biobased producten zijn nu nog niet geharmoniseerd in Europa, want alle lidstaten hebben een eigen biomassabeleid voor biobrandstoffen. Er is wel een Europese directive op dit gebied ten aanzien van biobrandstoffen (The Renewable Energy Directive 2009/28/EC). Dit beleid voor biobrandstoffen biedt aanknopingspunten voor duurzame biobased materialen. Anderen vinden het beleid voor biobrandstoffen onvoldoende, omdat het geen rekening houdt met (in)directe veranderingen in landgebruik (LUC en ILUC), zoals in negatieve zin minder voedselzekerheid en meer ontbossing in Amerika (Carus et al., 2016). Voorbeelden van positieve mitigatiestrategieen zijn eerder genoemd in par. 2.4 .

\section{Tools voor consumenten}

Aangezien biobased plastics vaak op fossiele plastics lijken, zijn ze voor de consument niet gemakkelijk te onderscheiden. Hetzelfde geldt voor afbreekbare plastics die niet eenduidig zijn gedefinieerd. Soms worden volgens een geïnterviewde door supermarkten onterechte claims gemaakt dat een plasticverpakking automatisch in de natuur afbreekbaar is (Natuur \& Milieu). Daarom is het belangrijk dat logo's en labels gekoppeld zijn aan een certificeringssysteem (Van den Oever et al., 2017).

Logo's en labels kunnen worden gebruikt om de consument (en retailer) duidelijk te maken of een plastic biobased en/of composteerbaar is en in welke container het plastic na gebruik kan worden weg gegooid. Dus of de verpakking naar het gft-afval, de papierbak of bij het plasticafval moet (Didde, 2017). Ook moeten belanghebbenden volgens de NEN nadenken over de congruentie van biobased afbreekbaar plastic met de rest van het product. Zo is een afbreekbare biobased verpakking belangrijk als de inhoud ervan dat ook is (zoals voedsel). Daarnaast hechten consumenten ook aan goede communicatie over biobased materialen, zoals een onafhankelijke partij (denk aan een natuurorganisatie) in plaats van het bedrijf als afzender, concrete boodschappen en het gebruik van logo's (Onwezen \& Reinders, 2017).

\section{Certificeringsschema's voor biobased materialen}

Certificeringsschema's zijn vrijwillige maatregelingen bovenop wetgeving waaraan iedereen zich moet houden. Certificeringschema's dragen bij aan het realiseren van een hoger niveau van duurzaamheid, kunnen worden aangepast aan de lokale omstandigheden en kunnen daarmee op een grotere steun van de belanghebbenden rekenen. De als duurzaam gecertificeerde biomassa is afhankelijk van het type biomassa dat wordt gebruikt (zoals tropisch hardhout, soja, palmolie en vis). Ook is de duurzaamheid van biomassa afhankelijk van de manier waarop het biobased materiaal is geproduceerd. De produktieprocessen bij zowel biobased als fossiele producten zijn echter complex, waardoor de duurzaamheid moeilijker is te meten dan bij brandstoffen. De NEN zou de verschillende maten van biodegredable voor biobased plastics willen normaliseren. Natuur \& Milieu zou een dergelijke claim voor biodegradable liever alleen wensen voor plastics die onder natuurlijke omstandigheden in korte tijd composteren en geen risico op ecologische schade leveren.

In landen zoals in Duitsland, Engeland en Frankrijk wordt de duurzaamheid van het product bepaald door de productie van biomassa en niet door de toepassing. In principe kunnen daarom de bestaande certificeringsschema's voor duurzame biobrandstoffen ook voor biobased materialen zoals biobased plastics worden gebruikt, mits ze worden aangepast (Vis \& Pfau, 2016). Better Biomass (zie Kader), de 'Roundtable on Sustainable Biomaterials' (RSB) en ISCC-PLUS hebben dit al gedaan. 
Better Biomass is een internationaal certificatiesysteem om de duurzaamheid van biomassa voor energie, brandstoffen en biobased producten aan te tonen. De duurzaamheidscriteria bevatten belangrijke waarden voor natuur, milieu en maatschappij, zijn opgezet door vertegenwoordigers van marktpartijen, overheid en maatschappelijke organisaties, en zijn gepubliceerd in de norm NTA 8080. Better Biomass wordt beheerd door het Nederlands Normalisatie-instituut (NEN), lid van CEN en ISO.

Bij de voorbereiding van de certificeringsschema's zijn ook natuurorganisaties betrokken geweest. Better Biomass en RSB besteden meer aandacht dan ISCC-Plus aan de impact van het telen van biomassa op de biodiversiteit, bodemvruchtbaarheid, overige milieuzaken en welzijn lokale gemeenschappen. Alle drie de certificeringsschema's besteden veel aandacht aan de impact van het telen van biomassa op de waterkwaliteit (Van Dam et al., 2010). Bij biodiversiteit gaat het om:

- Primary forests specifically mentioned (alleen ISCC-Plus);

- Biodiverse grassland specifically mentioned (allen);

- New plantings specifically mentioned (allen);

- Nature protected areas by relevant authority (nat. level) (allen);

- Protected areas recognised by international agreements (Ramsar, Kyoto, CBD) (Better Biomass \& RSB);

- Protected areas in lists drawn up by IUCN (Better Biomass \& RSB);

- Protected areas defined by stakeholder process (alleen RSB);

- Additional criteria (Better Biomass \& RSB).

Indirect landgebruik (ILUC) kan een belangrijk issue worden voor olie, suiker en zetmeelhoudende gewassen (niet voor lignocellulose). Bij Better Biomass (NEN) is een module 'ILUC-safe' opgenomen over de teelt van biomassa op voorheen marginale gronden, bij vruchtwisseling en in geval van het leveren van extra productie. Deze module is onlangs vastgesteld en nog niet gebruikt door certificaathouders van Better Biomass.

De vraag bij het standaardiseren en certificeren van biobased materialen is in hoeverre duurzame biomassa belangrijk gaat worden. Bij biobrandstoffen zijn de criteria hiervoor wettelijk vastgelegd, maar op een laag ambitieniveau. Bij biobased materialen worden criteria vrijwillig via certificering vastgelegd. Dit leidt tot een hoger ambitieniveau, maar minder bereik. Wel blijkt de certificering van andere biomassa communicatief gezien een sterk instrument te zijn geweest (NEN). Zo vindt men het belangrijk dat er keurmerken ontstaan die borgen dat de biomassateelt niet ten koste gaat van regenwoud of andere rijke ecosystemen, vergelijkbaar met 'Round Table on Responsible Soy (RTRS)' voor soja.

Natuur \& Milieu verwacht meer van wetgeving om milieuclaims te onderbouwen dan van certificering, al is ze huiverig voor de legitimering die hiervan uitgaat, dat wil zeggen dat het gebruik van biomassa voor biobased materialen acceptabel wordt. Uiteindelijk gaat het voor Natuur \& Milieu eerst om de hoeveelheid biomassa die er gebruikt wordt in relatie tot andere diensten die de landbouwgrond en natuur kunnen leveren. Gebruik van landbouwgrond voor voedseltoepassingen staat hierbij voorop. Wanneer het areaal niet voor voedseltoepassingen bruikbaar is, moet zij aan eisen voldoen zoals hiervoor gesteld bij biodiversiteit. Daarbij kan een keurmerk helpen om de eisen te realiseren.

Geïnterviewden vinden sowieso dat de duurzaamheidsclaims meer wetenschappelijk onderbouwd moeten worden, niet alleen voor biobased plastics maar ook in vergelijking met fossiel-based plastics.

$\mathrm{Bij}$ voedselclaims is de wetgeving en wetenschappelijke onderbouwing zeer streng, bij duurzaamheidsclaims niet (Natuur \& Milieu, NEN).

\subsection{Vraag vanuit de markt}

Voor nieuwe biobased en circulaire producten is marktonwikkeling essentieel. Er ontbreekt een stabiele vraag naar biobased plastics vanwege gebrek aan acceptatie van de prijs, functionaliteit en duurzaamheid van het product. Zo is de huidige prijs vaak hoger dan hun fossiele equivalent, terwijl drop-in biobased plastics geen functionele voordelen bieden. De vraag is of biobased producten zich op meer duurzaamheid of op betere gebruikseigenschappen moeten richten (NEN). 
Bedrijfsdeskundigen verwachten dat de toekomstige vraag voor bio-gebaseerde producten eerder afhankelijk is van de milieuwetgeving dat een circulaire economie stimuleert en openbare aanbestedingen bevordert dan van een groene premie die consumenten bereid zijn te betalen. Opgemerkt is ook dat de chemische industrie zich veel verder heeft kunnen optimaliseren in het maken van fossiele producten, waardoor er een oneerlijke concurrentie met biobased ontstaat. Zo werden bij de fossiele equivalenten de kosten van vervuiling niet doorberekend en was er geen LCA.

\section{Wetgeving om de vraag naar biobased plastics bij consumenten te stimuleren in Europa} Italiaanse consumenten zijn nu de grootste gebruiker van biobased plastics. Dit komt met name door hun wetgeving die het gebruik van afbreekbare biomassa in plasticverpakkingen verplicht (Dammer et al., 2017; Imbert et al., 2017). Andere Europese landen met een behoorlijke consumptie van biobased plastics zijn: Nederland, België, Duitsland, Oostenrijk en Zwitserland (Kaeb et al., 2016). De wetgeving in deze landen is echter niet gericht op het gebruik van meer biobased plastic verpakkingen, maar op het reduceren van het eenmalig gebruik van plastic verpakkingen. In Nederland is er volgens een geïnterviewde (BBD) tevergeefs gelobbyd om te zorgen dat er meer biobased afbreekbaar plastic wordt gebruikt. Frankrijk combineert verschillende perspectieven en wil het eenmalig gebruik van fossiele plastic tasjes en servies ontmoedigen ten gunste van hun biobased plastic equivalenten. In veel landen bestaat nog geen wetgeving op dit terrein (Dammer et al., 2017). Op EU-niveau wordt wetgeving voorbereid om het gebruik van biobased plastics in verpakkingen te stimuleren (docs.european-bioplastics.org/PR/2017/EUBP_PR_MEPs_pave_way_for_bioplastics_20170314.pdf).

\section{Duurzaam inkopen door overheden en bedrijven}

Inkoop van overheden en grote bedrijven kan de zich ontwikkelende biobased afzetmarkt stimuleren. De rol van de overheid als aanjager van de marktvraag (launching customer) is in Europa beperkter dan in Amerika (FBR). Een voorbeeld is het 'bio-preferred' programma in de Verenigde Staten (BBD). Waar in Nederland van een product het aandeel (zeg 10\%) vervangbaar fossiel door een percentage (100\%) biomassa berekend wordt als aandeel biobased in het totale product $(10 \%)$, wordt het in de Verenigde Staten berekend als aandeel biobased (100\%). Door dit groter getoonde aandeel is in de Verenigde Staten meer motivatie bij overheden om duurzaam in te kopen met biobased. Biobased Delta wil overheden en multinationals binnen haar regio scherp houden om hun rol te pakken bij biobased inkopen en het bieden van experimenteer ruimte voor het testen van nieuwe producten (BBD, 2017). Een voorbeeld van een multinationaal bedrijf dat indirect het gebruik van biobased plastic verpakkingen stimuleert, is Unilever dat in 2025 voor al haar producten (inclusief klein materiaal als zakjes, velletjes en koffiecapsules) $100 \%$ herbruikbare of composteerbare plastic verpakkingen wil gaan gebruiken.

Er lopen Europese projecten om het duurzaam inkopen van overheden te bespoedigen door het opzetten van Green Public Procurement (GPP)-schema's. Inkopers van duurzame producten accepteren in hun GPP-schema's biobased producten als deze op een geloofwaardige manier een breder scala aan milieuvoordelen kunnen tonen (Meeusen et al., 2015). GPP is een vrijwillig instrument. Om effectief te zijn, vereist GPP duidelijke en controleerbare milieucriteria voor producten en diensten in de toekenning van overheidsopdrachten. De Europese Commissie en een aantal Europese landen hebben richtlijnen ontwikkeld in de vorm van nationale GPP-criteria. De uitdaging is om meer overheidsinstanties hiertoe aan te zetten en te zorgen dat de groene inkoopvoorwaarden (enigszins) vergelijkbaar zijn tussen de lidstaten, waardoor een 'level-playing-field' ontstaat en de markt voor milieuvriendelijke goederen en diensten zal stimuleren.

\section{Branding en begrip van biobased}

Verder is de branding van biobased producten nog niet in staat om consumenten te trekken, omdat potentiële kopers de betekenis van het begrip biobased niet begrijpen. Dit geldt niet alleen in Nederland, maar ook in andere Europese landen (Sijtsema et al., 2016; Blesin et al., 2017). Zowel consumenten als inkopers van duurzame producten vinden het gebruik van biomassa onvoldoende als valide milieu-attribuut om meer te gaan betalen. De voorkeuren van consumenten voor biobased producten zijn vooral gericht op persoonlijke voordelen gerelateerd aan de prijs en functionaliteit van het biobased product (Sijtsema et al., 2016). Verder leidt het gebruik van het begrip 'bio' tot te positieve verwachtingen als dat het plastic volledig van plantaardig materiaal zou zijn gemaakt, dat de biomassa ecologisch is geteeld, niet-toxisch is en volledig afbreekbaar zou zijn (Bolck, 2017). Wanneer 
deze verwachtingen niet blijken te kloppen, ontstaat onzekerheid onder consumenten. Daarnaast kan het gebruik van het begrip 'bio' tot negatieve verwachtingen leiden als dat het plastic duurder en minder lang houdbaar zou zijn (Blesin et al., 2017).

\section{Maatschappelijke betrokkenheid}

Burgers en hun vertegenwoordigende organisaties zijn nauwelijks betrokken bij het ontwikkelen van de vraag. Vertegenwoordigers van ngo's dragen bij aan het opstellen van certificeringsschema's, maar zien voor zichzelf nauwelijks een rol om de vraag te stimuleren. Als men burgers bij de biobased economie wil betrokken, zal dit niet een doel op zichzelf moeten staan, maar in het teken van een bijdrage aan maatschappelijke doelen moeten staan zoals het gebruik van minder nieuwe fossiele grondstoffen voor de circulaire economie (Charles et al., 2015). De gemeente Bergen op Zoom heeft verschillende activiteiten georganiseerd om haar burgers vertrouwd te maken met het gebruik van biobased producten (tentoonstellingen in een pop-up store en in stands tijdens lokale evenementen).

Sommige geïnterviewden verwachten dat voor het overgrote deel van de kunststoffen fossiel nog lange tijd een belangrijke grondstof zal blijven (Natuur \& Milieu). Verduurzaming zal in de eerste plaats van meer recycling moeten komen. Pas daarna kan biobased ketenverliezen in de kringloop aanvullen (Natuur \& Milieu). Het biodegradable deel zal vooral zijn functie moeten vinden op plekken waar vanuit de functionaliteit van de toepassing dit toegevoegde waarde heeft. Congruentie is ook voor de natuur belangrijk. Bij kunststoffen, waarvan het onvermijdelijk is dat die in de natuur terecht komen, is het belangrijk om onder natuurlijke omstandigheden van biologisch afbreekbaar materiaal te zijn (Natuur \& Milieu). 


\section{$4 \quad$ Slotbeschouwing}

\subsection{Conclusies}

In de Inleiding is aangegeven dat het gebruik van biobased materialen niet alleen een uitdaging vormt voor het stimuleren van de circulaire economie en goed landgebruik, maar ook meer inzicht vraagt. De volgende twee vragen dienen hierbij als leidraad waarbij wij ons richten op biobased plastics.

\section{Hoe kan de relatie tussen het gebruik van biomassa in plastics, circulaire economie en landgebruik empirisch worden geduid?}

Biobased materialen zijn (deels) gemaakt van plantaardige grondstoffen en worden vooral in verpakkingen toegepast. De bijdrage van biobased plastics aan de circulaire economie is nog beperkt. Zo zijn er nog weinig producten en kunnen deze vaak niet worden afgebroken zoals bio-petflessen en bio-PE draagtassen en flacons. Slechts een klein deel van de biobased plastics is wel biologisch afbreekbaar zoals polymelkzuur (PLA) in plastic bakjes, folies en foam als voedselverpakking. Onduidelijk is of en hoe snel het ook in de natuur kan worden afgebroken en op de composthoop mag. Daarom is het belangrijk dat er een normalisatie en certificatie-systeem komt met logo's en labels die dit aan gebruikers duidelijk maken.

Wereldwijd is het gebruik aan land voor biomassa voor plastics kleiner dan voor biobrandstoffen en vele malen kleiner dan voor voedsel. In Nederland zijn volgens een eerste berekening veel te weinig hectares cultuurgrond beschikbaar voor het telen van biomassa om de binnenlandse vraag naar fossiele kunststoffen volledig te vervangen, tenzij wij op dit areaal alleen suikerbieten zouden gaan telen. 'Nederland bietenland' wordt voorlopig geen werkelijkheid, want de chemische industrie verwacht in 2030 maar een klein deel van het benodigde biobased materiaal te kunnen leveren. Maar ook het voorzien in de technisch haalbare behoefte aan biomassa betekent al bijna een verdubbeling van het huidige areaal aan suikerbieten. Andere oplossingen die minder extra land vragen, zijn meer gebruik van reststromen, een intensiever landgebruik en meer hergebruik van fossiele plastics. Biobased plastic wordt gezien als een duurzaam alternatief voor fossiel geproduceerd plastic, gezien de grondstoffenzekerheid en de lagere uitstoot van $\mathrm{CO}_{2}$. De impact op eutrofiëring en verzuring en het vrijkomen van $\mathrm{N}_{2} \mathrm{O}$ is echter groter.

\section{Welke uitdagingen zijn er voor een transitie naar duurzame biobased plastics?}

Gegeven de grote hoeveelheid cultuurgrond dat nodig is voor het telen van biomassa voor plastics (eerste generatie), kan meer gebruik van reststromen (tweede generatie) uitkomst bieden. Dit gebeurt nu nog niet. De huidige afvalwetgeving werkt belemmerend als grondstoffen de afvalstatus hebben. Een versoepeling van de afvalwetgeving helpt om de hele plant, inclusief reststromen, in te zetten. Ook in de voorlopende regio's is nog nauwelijks een waardeketen ontwikkeld dat alle actoren van boer tot consument verbindt en tot een maatschappelijke vraag naar biobased plastics leidt. De meeste aandacht gaat uit naar het samen ontwikkelen van halffabrikaten en het verbinden van actoren in de biobased industrie.

Duurzaamheidsaspecten van biomassa voor biobased materialen zijn niet geharmoniseerd in Europa. Alle lidstaten hebben een eigen biomassa beleid. Het beleid voor biobrandstoffen biedt aanknopingspunten voor duurzame biobased materialen. De rijksoverheid wil hiervoor soortgelijke voorwaarden hanteren. Anderen vinden dit beleid onvoldoende, omdat het geen rekening houdt met (in)directe veranderingen in landgebruik, voedselzekerheid en ontbossing. Certificeringsschema's kunnen een bijdrage leveren aan extra afspraken over duurzaamheid. Bestaande certificeringsschema's voor duurzame biobrandstoffen zijn aangepast voor biobased materialen (Better Biomass, RSB en ISCCPLUS). Een belangrijke behoefte voor wetgeving en certificering is dat de duurzaamheidsclaims wetenschappelijk beter worden onderbouwd. 
Er ontbreekt nu een stabiele vraag naar biobased plastics, omdat deze qua prijs en functie nog nauwelijks voordelen bieden ten opzichte van fossiele plastics. Biobased ontwikkelingen zouden zich meer op de eigenschappen van de gebruikte biomassa moeten richten (minder gewicht, betere afbreekbaarheid, langere houdbaarheid). Verder begrijpen potentiele kopers de betekenis van het begrip biobased niet. In Nederland is geen wetgeving dat het gebruik van biobased (indirect) stimuleert. Op EU-niveau wordt wetgeving voorbereid om het gebruik van biobased plastics in verpakkingen te stimuleren. Er ontbreekt een tool waarmee op basis van people, planet en profit een afweging kan worden gemaakt welke toepassing van biomassa (van brandstof tot en met cosmetica) het meest zinvol is.

\subsection{Aandachtspunten voor verder onderzoek}

Het gaat om onderzoek dat het maatschappelijk belang van de bijdrage van biobased materialen aan de circulaire economie kan versterken.

1. Meer duurzaam gebruik van grondstoffen en reststromen voor biobased plastics Uit het onderzoek blijkt dat Nederland in de toekomst zelf onvoldoende biomassa kan telen en verwerken om de vraag naar biobased plastics te voldoen. Naast het gebruik van meer land om suikerbieten te telen, kan echter ook worden gedacht aan meer gebruik van reststromen, een intensiever landgebruik en meer hergebruik van fossiele plastics. De vraag is echter of restromen hiervoor kunnen worden ingezet, of intensiever landgebruik niet ten koste gaat van de bodemkwaliteit en in hoeverre plastics kunnen worden hergebruikt. In hoeverre zijn deze opties mogelijk?

\section{Meer aandacht voor integrale afweging van duurzaamheid}

Duurzaamheidsclaims zouden meer wetenschappelijk onderbouwd worden. Daarnaast zijn er nieuwe concepten nodig die people, planet en profit beter integreren om een afweging van de toepassing van biomassa te maken voor respectievelijk brandstoffen, materialen, voedsel of cosmetica. Certificeringsschema's kunnen een bijdrage leveren aan meer vrijwillige afspraken over duurzaamheid en kunnen consumenten helpen om biobased beter te begrijpen bij hun afvalmanagement. 


\section{Literatuur}

Accenture (2017). Taking the European chemical industry into the circular economy. Executive Summary. BBD (2017). Meerjarenplan Stichting Biobased Delta 2018-2020. Stichting Biobased Delta.

Blesin, J-M., M. Jaspersen \& W. Möhring (2017). Boosting Plastics' Image? Communicative Challenges of Innovative Bioplastics. E-Plastory. http://e-plastory.com. ISSN 2190-9598

Bolck, C., J. Ravenstijn, K. Molenveld \& P. Harmsen (2012). Biobased Plastics 2012. Wageningen UR Food \& Biobased Research

Bolck, C. (2017). Bioplastic: feiten en fictie, Resource 11(2017)19 p. 18-19, http://edepot.wur.nl/417017

Brinkmann, A. (2014). Biomassa als grondstof of als brandstof - praktijkvoorbeelden van ongewenste concurrentie om Nederlandse biomassastromen. Brinkmann Consultancy

Carus, M., A. Raschka, K. Iffland, L. Dammer, R. Essel \& S. Piotrowski (2016). HOW TO SHAPE The Next Level of The European Biobased Economy? (originally published in renewablematter 08. 2016)

CBS Statline (2017). Statistiek energieverbruik industrie. CBS, Den Haag.

Charles, D., S. Davies, S. Miller, K. Clement, G. Overbeek, A-C Hoes, M. Hasenheit, Z. Kiresiewa, S. Kah, C. Bianchini, C. (2016). BioSTEP deliverable 3.2. Case studies of regional bioeconomy strategies across

Europe. www.biobasedeconomy.eu/research/open-bio

CPB (2017). De circulaire economie van kunststof: van grondstoffen tot afval.

Dammer, L., M. Carus, K. Iffland, S. Piotrowski, L. Sarmento, R. Chinthapalli \& A. Raschka (2017). Current situation and trends of the biobased industries in Europe. Pilot Study for BBI JU

Didde, R. (2017). Duurzamer verpakken. Wageningen World. 3(2017) p. 34-39.

Ellen MacArthur Foundation (2017). Beyond plastic waste. Science 358( 2017) 6365, p. 843

EZ (2015). Biomassa 2030. Strategische visie voor de inzet van biomassa op weg naar 2030. Publicatienummer 89293. Ministerie van Economische Zaken, Den Haag.

IenM \& EZ (2016). Nederland circulair in 2015. Ministerie van Infrastructuur en Milieu, en Economische Zaken, Den Haag

Imbert, E., L. Ladu, P. Morone \& R. Quitzow (2017). Comparing policy strategies for a transition to a bioecony in Europe: The case of Italy and Germany. Energy Research \& Social Science.

Kaeb, H., Fl. Aeschelmann, L. Dammer, M. Carus (2016). Market study on the consumption of biodegradable and compostable plastic products in Europe 2015 and 2020. Nova Institute for Ecology and Innovation.

Meeusen, M., J. Peuckert \& R. Quitzow (2015). Open-BIO deliverable 9.2: Acceptance factors for biobased products and related information systems. www.biobasedeconomy.eu/research/open-bio

Natuur \& Milieu (2017). Biomassavisie. Welke rol speelt biomassa in een duurzame toekomst?

Molenveld, K en M. van den Oever (2014). Catalogus biobased verpakkingen. Wageningen UR Food \& Biobased Research (ISBN 978-94-6173-704-5)

Onwezen, M. \& M. Reinders (2017). Consumer acceptance of Bio-based food packaging - Results of quantitative research Germany and France. Deliverable COMBO project.

PBL (2014). Infographic biomassa. Planbureau voor de Leefomgeving, Den Haag.

Rabou et al., PGG, ECN \& WUR (2006). Biomassa in de Nederlandse energiehuishouding in 2030.

Rood, T \& A. Hanemaaijer (2014). Reflectie op Van Afval Naar Grondstof (VANG), PBL-notitie (2014). Planbureau voor de Leefomgeving, Den Haag.

RVO (2017). Monitoring biobased economy. Rijksdienst voor Ondernemend Nederland, Utrecht.

Sanders, J. (2014). Biorefinery. The bridge between Agriculure and Chemistry. Farewell speech. Wageningen University \& Research, Wageningen.

Sijtsema, S.J., M.C. Onwezen, M.J. Reinders, H. Dagevos, A. Partanen \& M. Meeusen (2016). Consumer perception of biobased products-An exploratory study in 5 European countries. NJAS - Wageningen Journal of Life Sciences, 77, 61-69. 
Spatial Foresight, SWECO, ÖIR, t33, Nordregio, Berman Group, Infyde (2017). Bioeconomy development in EU regions. Mapping of EU Member States'/regions' Research and Innovation plans \& Strategies for Smart Specialisation (RIS3) on Bioeconomy for 2014-2020. Study commissioned by DG Research \& Innovation, European Commission. Brussels.

Van Dam, J., Junginger, M., \& Faaij, A. P. C. (2010). From the global efforts on certification of bioenergy towards an integrated approach based on sustainable land use planning. Renewable and Sustainable Energy Reviews doi:10.1016/j.rser.2010.07.010

Van den Oever, M., K. Molenveld, M. van der Zee \& H. Bos (2017): Biobased and biodegradable plastics Facts and Figures. Wageningen Food \& Biobased Research number 1722.

Vis, M. \& S. Pfau (2016). Open-BIO deliverable 3.6 Biobased sustainability schemes. Enschede, BTG Biomass Technology Group. www.biobasedeconomy.eu/research/open-bio

Woltjer, G., V. Daioglou, B. Elbersen, G. Barberena Ibañez, E. Smeets, D. Sánchez González \& J. Barnó (2017). Study report on reporting requirements on biofuels and bioliquids stemming from the directive (EU). European Commission. 2015/1513

WPI (2009). Assessment of the Impacts of Bioplastics: Energy Usage, Fossil Fuel Usage, Pollution, Health Effects, Effects on the Food Supply, and Economic Effects Compared to Petroleum Based Plastics. Worcester Polytechnic Institute.

\section{Geraadpleegde websites}

www.biobasedcontent.eu

www.european-bioplastics.org

www.groenegrondstoffen.nl 


\section{Verantwoording}

Deze voorstudie toont het zoekproces vanuit een maatschappelijk perspectief bij stakeholders en onderzoekers in de wereld van chemie en natuur. Wij zijn daarbij ondersteund door een meedenkende opdrachtgever van het Planbureau voor de Leefomgeving (PBL), Arjan Ruijs, en de WOT-themacoördinator, Martijn van der Heide.

We hebben deskundigen geïnterviewd die op verschillende manieren bij de transitie naar een biobased economie zijn betrokken, namelijk Christiaan Bolck (Wageningen Food en Biobased Research), Harmen Willemse (NEN), Jelmer Vierstra (Stichting Natuur \& Milieu) en Rop Zoetemeyer (Stichting Biobased Delta).

Wij danken de geïnterviewden voor de gesprekken en hun reviews van het rapport en de opdrachtgevers voor hun bijdrage aan de realisatie ervan. 


\section{Verschenen documenten in de reeks \\ Technical reports van de Wettelijke Onderzoekstaken Natuur \& Milieu vanaf 2016}

WOt-technical reports zijn verkrijgbaar bij het secretariaat van Unit Wettelijke Onderzoekstaken Natuur \& Milieu te Wageningen. T 0317 - 4854 71; E info.wnm@wur.nl

WOt-technical reports zijn ook te downloaden via de website www.wur.nl/wotnatuurenmilieu

61 Berg, F. van den, A. Tiktak, J.J.T.I. Boesten \& A.M.A. van der Linden (2016). PEARL model for pesticide behaviour and emissions in soil-plant systems; Description of processes

62 Kuiters, A.T., G.A. de Groot, D.R. Lammertsma, H.A.H. Jansman \& J. Bovenschen (2016). Genetische monitoring van de Nederlandse otterpopulatie; Ontwikkeling van populatieomvang en genetische status 2014/2015

63 Smits, M.J.W., C.M. van der Heide, H. Dagevos, T. Selnes \& C.M. Goossen (2016). Natuurinclusief ondernemen: van koplopers naar mainstreaming?

64 Pouwels, P. , M. van Eupen, M.H.C. van Adrichem, B. de Knegt \& J.G.M. van der Greft (2016). MetaNatuurplanner v2.0. Status $A$

65 Broekmeyer, M.E.A. \& M.E. Sanders (2016). Natuurwetgeving en het omgevingsrecht. Achtergrond-document bij Balans van de Leefomgeving, 2014

66 Os, J. van, J. H.S.D. Naeff \& L.J.J. Jeurissen (2016).Geografisch informatiesysteem voor de emissieregistratie van landbouwbedrijven; GIABplus-bestand 2013 - Status $A$

67 Ingram, V.J., L.O. Judge, M. Luskova, S. van Berkum \& J. van den Berg (2016). Upscaling sustainability initiatives in international commodity chains; Examples from cocoa, coffee and soy value chains in the Netherlands.

68 Duin van W.E., H. Jongerius, A. Nicolai, J.J. Jongsma, A. Hendriks \& C. Sonneveld (2016). Friese en Groninger kwelderwerken: Monitoring en beheer 1960-2014.

69 Ehlert, P.A.I., T.A. van Dijk \& O. Oenema (2016). Opname van struviet als categorie in het Uitvoeringsbes/uit Meststoffenwet. Advies.

70 Ehlert, P.A.I., H.J. van Wijnen, J. Struijs, T.A. van Dijk, L. van Schöll, L.R.M. de Poorter (2016). Risicobeoordeling van contaminanten in afval- en reststoffen bestemd voor gebruik als covergistingsmateriaal

71 Commissie Deskundigen Meststoffenwet (2016). Protocol beoordeling stoffen Meststoffenwet. Versie 3.2

72 Kramer, H., J. Clement (2016). Basiskaart Natuur 2009. Een landsdekkend basisbestand voor de terrestrische natuur in Nederland

73 Dam, R.I. van, T.J.M. Mattijssen, J. Vader, A.E. Buijs \& J.L.M. Donders (2016). De betekenis van groene zelf-governance. Analyse van verschillende vormen van dynamiek in de praktijk.
74 Hennekens, S.M., M. Boss \& A.M. Schmidt (2016). Landelijke Vegetatie Databank; Technische documentatie, Status A

75 Knegt, B. de, et al. (2016). Kansenkaarten voor duurzaam benutten van Natuurlijk Kapitaal

76 Commissie Deskundigen Meststoffenwet (2016). Advies 'Mestverwerkingspercentages 2017'

77 W.H.J. Beltman, C. Vink \& A. Poot (2016). Calculation of exposure concentrations for NL standard scenarios by the TOXSWA model; Use of FOCUS_TOXSWA 4.4.3 software for plant protection products and their metabolites in Dutch risk assessment for aquatic ecosystems

78 Koffijberg K., J.S.M. Cremer, P. de Boer, J. Postma \& K. Oosterbeek \& J.S.M. Cremer (2016). Broedsucces van kustbroedvogels in de Waddenzee in 2014.

79 Sanders, M.E. G.W.W Wamelink, R.M.A. Wegman \& J. Clement (2016). Voortgang realisatie nationaal natuurbeleid; Technische achtergronden van een aantal indicatoren uit de digitale Balans van de Leefomgeving 2016

80 Vries, S. de \& I.G. Staritsky (2016). AVANAR 2.0 nader beschreven en toegelicht; Achtergronddocumentatie voor Status $A$.

81 Kuiters, A.T., G.A. de Groot, D.R. Lammertsma, H.A.H. Jansman \& J. Bovenschen (2016). Genetische monitoring van de Nederlandse otterpopulatie; Ontwikkeling van populatieomvang en genetische status 2015/ 2016.

82 Pleijte, M., R. Beunen \& R. During (2016). Rijksprojecten: hét natuurinclusieve werken? Een analyse van relaties tussen rijksprojecten en de Rijksnatuurvisie

83 Smits, M.J.W. en E.J. Bos (2016). Het stimuleren van ondernemen met natuur: handelingsopties voor de overheid

84 Horst, M.M.S. ter, W.H.J. Beltman \& F. van den Berg (2016). The TOXSWA model version 3.3 for pesticide behaviour in small surface waters; Description of processes

85 Mattijssen, T.J.M. (2016). Ideaaltypen en analysekader van groene burgerinitiatieven; Bijlage bij het rapport 'De betekenis van groene burgerinitiatieven: analyse van kenmerken en effecten van 264 initiatieven in Nederland'

86 Wösten, J.H.M., F. de Vries \& J.G. Wesseling (2016). BOFEK2012 versie 2; Status $A$

87 Pleijte, M., R. During \& R. Michels (2016). Nationale parken in transitie; governance-implicaties van een veranderend beleidskader

88 Mol-Dijkstra, J.P.\& G.J Reinds (2017). Technical documentation of the soil model VSD+; Status $A$

89 Arets, E.J.M.M., J.W.H van der Kolk, G.M. Hengeveld, J.P. Lesschen, H. Kramer, P.J. Kuikman \& M.J. Schelhaas (2017). Greenhouse gas reporting for the LULUCF sector in the Netherlands. Methodological background, update 2016

90 Bruggen, C. van, A. Bannink, C.M. Groenestein, J.F.M. Huijsmans, H.H. Luesink, S.V. Oude Voshaar, S.M. van der Sluis, G.L. Velthof \& J. Vonk (2017). 
Emissies naar lucht uit de landbouw in 2014 Berekeningen met het model NEMA

91 Os van, J., M.G.T.M. Bartholomeus, L.J.J. Jeurissen \& C.G. van Reenen (2017). Rekenregels rundvee voor de landbouwtelling. Verantwoording van het gebruik van I\&R gegevens voor de landbouwtelling

92 Haas, W. de, R.J. Fontein \& M. Pleijte (2017). Is eenvoudig beter? Twee essays natuur en landschap in het nieuwe omgevingsbeleid

93 Schuiling, C., A.M. Schmidt, I.J. La Rivière \& R.A. Smidt (2017). Beschermde gebiedenregister; Technische documentatie, Status A.

94 Henkens, R.J.H.G., M.M.P. van Oorschot en J. Ganzevles (2017). Bijdrage van Green Deals aan de beleidsdoelen voor natuur en biodiversiteit

95 Arets, E.J.M.M., J.W.H van der Kolk, G.M. Hengeveld, J.P. Lesschen, H. Kramer, P.J. Kuikman \& M.J. Schelhaas (2017). Greenhouse gas reporting for the LULUCF sector in the Netherlands. Methodological background, update 2017

96 IJsseldijk, L.L., M.J.L. Kik, L. Solé \& A. Gröne (2017). Postmortaal onderzoek van bruinvissen (Phocoena phocoena) uit Nederlandse wateren, 2016.

97 Verburg, R.W., W.H.G.J. Hennen, L.F. Puister, R. Michels \& K. van Duijvendijk (2017). Estimating costs of nature management in the European Union; Exploration modelling for PBL's Nature Outlook

98 Bruggen, C. van, A. Bannink, C.M. Groenestein, J.F.M. Huijsmans, H.H. Luesink, S.V. Oude Voshaar, S.M. van der Sluis, G.L. Velthof \& J. Vonk (2017). Emissies naar lucht uit de landbouw in 2015. Berekeningen met het model NEMA

99 Kuiters, A.T., G.A. de Groot, D.R. Lammertsma, H.A.H. Jansman \& J. Bovenschen (2017). Genetische monitoring van de Nederlandse otterpopulatie; Ontwikkeling van populatieomvang en genetische status 2016/2017

100 Adriaanse, P.I. \& W.H.J Beltman (2017) Comparison of pesticide concentrations at drinking water abstraction points in The Netherlands simulated by DROPLET version 1.2 and 2.0

101 Daamen, W.P., A.P.P.M. Clerkx \& M.J. Schelhaas (2017). Veldinstructie Zevende Nederlandse Bosinventarisatie (2017-2021).

102 Boer, T.A. de \& F.L. Langers (2017). Maatschappelijk draagvlak voor natuurbeleid en betrokkenheid bij natuur

103 Buijs, A.E., B.H.M. Elands \& C.S.A. van Koppen (2017) 25 jaar burgerbetrokkenheid in het natuurbeleid. Analyse van beleidsdiscoursen en publiek draagvlak

104 Cremer, J.S.M., S.M.J.M. Brasseur., A. Meijboom, J. Schop \& J.P. Verdaat (2017). Monitoring van gewone en grijze zeehonden in de Nederlandse Waddenzee, 2002-2017

105 Glorius, S.T., A. Meijboom, J.T. van der Wal \& J.S.M. Cremer (2017). Ontwikkeling van enkele mosselbanken in de Nederlandse Waddenzee, situatie 2016
106 Hennekens, S.M., W.A. Ozinga \& J.H.J. Schaminée (2017). BioScore 3 - Plants. Background and preprocessing of distribution data

107 Melman, Th.C.P., M.H.C. van Adrichem, M. Broekmeyer, J. Clement, R. Jochem, H.A.M. Meeuwsen, F.G.W.A. Ottburg, A.G.M. Schotman \& T. Visser (2017). Bijdrage natuurcombinaties aan landelijke natuurdoelstelling buiten NNN; Verkenning van een methodiek, gebaseerd op ecologische modellen

109 Overbeek, M.M.M., E. Smeets \& D. Verhoog (2017). Biobased materialen, circulaire economie en natuurlijk kapitaal. 



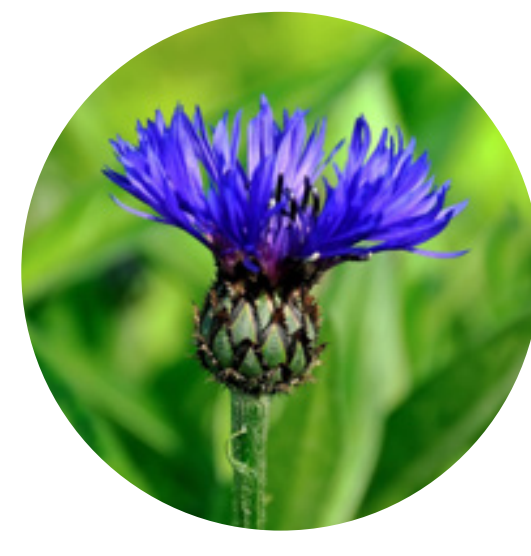

Thema Periodieke Evaluatie

Natuurbeleid

Wettelijke Onderzoekstaken Natuur \& Milieu

P.O. Box 47

6700 AA Wageningen

T (0317) 485471

E info.wnm@wur.nl

ISSN 2352-2739

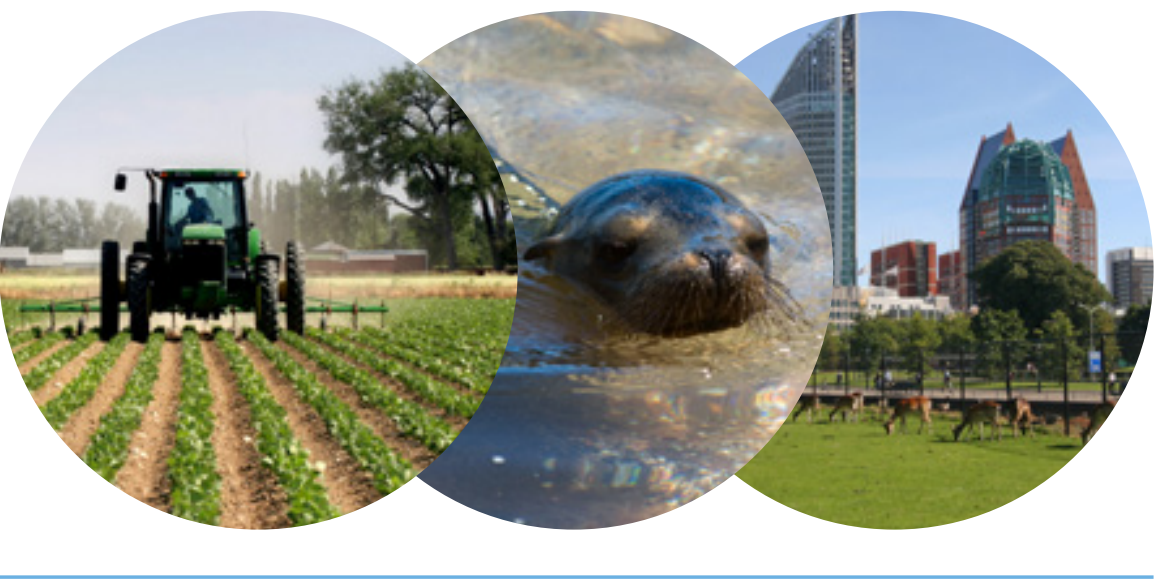

De missie van Wageningen University \& Research is 'To explore the potential of nature to improve the quality of life'. Binnen Wageningen University \& Research bundelen 9 gespecialiseerde onderzoeksinstituten van Stichting Wageningen Research en Wageningen University hun krachten om bij te dragen aan de oplossing van belangrijke vragen in het domein van gezonde voeding en leefomgeving. Met ongeveer 30 vestigingen, 5.000 medewerkers en 10.000 studenten behoort Wageningen University \& Research wereldwijd tot de aansprekende kennisinstellingen binnen haar domein. De integrale benadering van de vraagstukken en de samenwerking tussen verschillende disciplines vormen het hart van de unieke Wageningen aanpak. 